\title{
Technological Challenges of Phosphorus Removal in High-Phosphorus Ores: Sustainability Implications and Possibilities for Greener Ore Processing
}

\author{
Stanley Udochukwu Ofoegbu ${ }^{1,2}$ (1) \\ 1 Centre for Mechanical Technology and Automation (TEMA), Department of Mechanical Engineering, \\ University of Aveiro, Campus Universitário de Santiago, 3810-193 Aveiro, Portugal; ofoegbu.stanley@ua.pt; \\ Tel.: +351-915-2486-42 \\ 2 Department of Materials and Ceramic Engineering, CICECO-Aveiro Institute of Materials, University of \\ Aveiro, Campus Universitário de Santiago, 3810-193 Aveiro, Portugal
}

Received: 28 October 2019; Accepted: 26 November 2019; Published: 29 November 2019

\begin{abstract}
With the present rates of iron ore consumption, currently unusable, high-phosphorus iron ore deposits are likely to be the iron ores of the future as higher-grade iron ore reserves are depleted. Consequently, the design and timely development of environmentally-benign processes for the simultaneous beneficiation of high-phosphorus iron ores and phosphorus recovery, currently a technological challenge, might soon become a sustainability challenge. To stimulate interest in this area, phosphorus adsorption and association in iron oxides/hydroxyoxides, and current efforts at its removal, have been reviewed. The important properties of the most relevant crystalline phosphate phases in iron ores are highlighted, and insights provided on plausible routes for the development of sustainable phosphorus recovery solutions from high-phosphorus iron ores. Leveraging literature information from geochemical investigations into phosphorus distribution, speciation, and mobility in various natural systems, key knowledge gaps that are vital for the development of sustainable phosphorus removal/recovery strategies and important factors (white spaces) not yet adequately taken into consideration in current phosphorus removal/recovery solutions are highlighted, and the need for their integration in the development of future phosphorus removal/recovery solutions, as well as their plausible impacts on phosphorus removal/recovery, are put into perspective.
\end{abstract}

Keywords: iron ores; phosphorus recovery; green economy; environmental impacts; sustainability

\section{Introduction}

Phosphorus is the 11th most abundant element on earth [1]. The adsorption of phosphates on mineral surfaces is of vital importance for a variety of reasons. For the soil scientist, agriculturist, and environmentalist, its absence or presence, transport, and interactions in soil and water sources are of great importance, as these contribute to determining the fertility of soil [2-6], and the possibility of water pollution [7-12] and consequent eutrophication [13-19]. However, for the extractive metallurgist focused on steel making, iron ores with phosphorus contents greater than $0.1 \mathrm{wt} . \%$ can be a problem. Besides the presence of significant quantities of phosphorus in minerals/ores, its presentation, distribution, and interaction with mineral surfaces are of vital importance, as these determine the ease or difficulty with which the ore can be beneficiated. From insights obtained from analyses of phosphorus content and distribution in high-phosphorus iron ores [20], it is posited that phosphorus can be present in ores in four principal forms: as distinct crystalline phase(s) in the iron-rich phase, as distinct crystalline phase(s) in the associated gangue mineral, as amorphous phase(s) or adsorbed phase(s) in the iron-rich fraction of the ore, as an amorphous phase(s) or adsorbed 
phase(s) in the gangue, or any combination of these, with implications on the appropriate phosphorus removal approach.

When present as a distinct crystalline or amorphous phase in iron ores, phosphorus can be finely distributed in the iron-rich phase, in the gangue mineral, or in both [20]. Its predominance in the gangue mineral makes phosphorus removal from ores easier, and amenable to the use of mechanical methods for its removal, while its presence in the iron-rich phase necessitates the application of other/additional methods (often chemical or thermal) to achieve phosphorus removal/reduction with associated economic and environmental costs. Table 1 illustrates the global distribution and presentation of phosphorus in high-phosphorus iron ores.

Due to the very high affinity of iron oxides and hydroxides for phosphorus, a phenomenon much exploited in environmental chemistry and waste water management to remove phosphorus from polluted water, phosphorus removal from iron ore is not a trivial process, particularly when the phosphorus is predominantly finely distributed and/or adsorbed onto mineral surfaces. The development of environmentally-benign processes to ensure our ability to exploit high-phosphorus iron ores, thereby maintaining a continued supply amidst increasing demand for the steel that has fueled industrial development, might rank highly among sustainability issues of the near future. As higher-grade ores (low phosphorus) are consumed, the fraction of remaining iron ore reserves comprised of lower-grade (high phosphorus) iron ores increases. This trend calls for the development of sustainable procedures to valorize and exploit high-phosphorus iron ores which are most likely to be the predominant iron ore grade of the future. For instance, China is reported [21] to be rich in high-phosphorus iron ores, constituting some $14.86 \%$ of total reserves and reaching $7.45 \mathrm{Gt}$, which places the country's total iron ore reserves at around $50 \mathrm{G}$ t. The global high-quality iron ore reserves are projected to be depleted within the next 20-40 years, leaving us with only low-grade ores [22].

This paper critically reviews some reports that have appeared in the literature in the last few years on the reactivity of mineral surfaces to phosphorus, theories on phosphate presence in iron oxides, and its adsorption to mineral (iron oxide) surfaces. Secondly, factors influencing phosphate adsorption to mineral (iron oxide) surfaces, and the kinetics of phosphorus adsorption and desorption from mineral (iron oxide/hydroxide) surfaces, are reviewed, highlighting their implications for research on phosphorus removal. Finally, insights are presented on plausible future research strategies for the development of more environmentally-sustainable phosphorus removal and recovery protocols/systems for high-phosphorus iron ores and other minerals containing phosphorus. Since phosphorus removal solely by thermal processing is seldom employed, and thermal processing is often an energy-intensive intermediate step prior to leaching, this review focuses on phosphorus removal and recovery strategies which are consistent with hydrometallurgical processing. 
Table 1. Global distribution and presentation of phosphorus in high-phosphorus iron ores.

\begin{tabular}{|c|c|c|c|c|}
\hline Ore Origin & Fe Content (wt. \%) & P Content (wt. \%) & P Presentation & Ref \\
\hline $\begin{array}{c}\text { Pilbara region of Western } \\
\text { Australia. }\end{array}$ & 62.1 & 0.126 & apatite & {$[23,24]$} \\
\hline $\begin{array}{l}\text { Brockman Iron Ore } \\
\text { Formation, Australia. }\end{array}$ & & $>0.1-1.3$ & $\begin{array}{l}\text { Apatite, vivianite, strengite, } \\
\text { wavellite }\end{array}$ & [25] \\
\hline $\begin{array}{c}\text { Iron Quadrangle (Minas } \\
\text { Gerais-Brazil) }\end{array}$ & & & Wavellite & [26] \\
\hline $\begin{array}{c}\text { Jangada mine, Quadrilátero } \\
\text { Ferrífero, Minas Gerais, } \\
\text { Brazil }\end{array}$ & & & $\begin{array}{c}\text { Senegalite, turquoise, } \\
\text { apatite, Crandallite, Giniite, } \\
\text { Gorceixite, Rockbridgeite, } \\
\text { Strengite, Turquoise, } \\
\text { Variscite, Wardite, Wavellite, } \\
\text { xenotime }\end{array}$ & [27-31] \\
\hline $\begin{array}{l}\text { Snake River iron-ore deposit, } \\
\text { northern Yukon, Canada }\end{array}$ & $\begin{array}{c}44^{*} \\
53.4^{* *}\end{array}$ & $\begin{array}{l}0.34^{*} \\
0.39^{* *}\end{array}$ & $\begin{array}{l}\text { Apatite, wavellite, } \\
\text { collophane }\end{array}$ & [32] \\
\hline West Hubei Province, China & 49.02 & 1.18 & collophanite & [33] \\
\hline Wushan, Chongqing China & & 1.16 & Apatite, fluorapatite & [21] \\
\hline Wushan Mountain in China & 45.11 & 0.72 & fluorapatite & [34] \\
\hline Wushan, Chongqing, China & 49.5 & 0.609 & apatite fluorapatite & [35] \\
\hline Changde iron ore, China & 47.79 & 1.12 & $\begin{array}{c}\text { Apatite } \\
(67.9 \% \mathrm{P} \text { in iron phase, } \\
\text { and } 9.8 \% \mathrm{P} \text { in silicate phase. })\end{array}$ & [36] \\
\hline $\begin{array}{l}\text { Huimin iron ore (Yunnan } \\
\text { Province), China } \\
{\left[2.0 \times 10^{9} \mathrm{t}\right]}\end{array}$ & $\begin{array}{l}43.50 \\
\text { Goethite Hematite }\end{array}$ & 0.85 & $\begin{array}{l}\text { amorphous grattarolaite } \\
\qquad\left(\mathrm{Fe}_{3} \mathrm{PO}_{7}\right)\end{array}$ & [37] \\
\hline Aswan, Egypt & & $0.13-1.49$ & hydroxyapatite & [38] \\
\hline Hesse, Germany & & & Allanpringite & [39] \\
\hline Chador-malu iron ore, Iran & 57.20 & $0.748 \%$ & Apatite & [40] \\
\hline $\begin{array}{l}\text { Lisakovsk, North } \\
\text { Kazakhstan }\end{array}$ & 48.76 & $0.6-0.8$ & $\begin{array}{l}\text { No distinct Phosphorus } \\
\text { mineral yet identified }\end{array}$ & {$[41,42]$} \\
\hline Agbaja iron ore, Nigeria & 54.17 & 2.69 & $\begin{array}{l}\text { Traces of phosphates of iron } \\
\text { and aluminum }\end{array}$ & [43] \\
\hline Agbaja iron ore, Nigeria & 53.1 & 1.395 & $\begin{array}{l}\text { No distinct Phosphorus } \\
\text { mineral yet identified }\end{array}$ & [20] \\
\hline $\begin{array}{c}\text { Koton-karfe iron ore, Nigeria } \\
{\left[4.28 \times 10^{8} \text { tons }\right]}\end{array}$ & $\begin{array}{l}46.91 \\
\text { Goethite }(\mathrm{FeO}(\mathrm{OH})) \\
\text { Magnetite }\left(\mathrm{Fe}_{3} \mathrm{O}_{4}\right) \text {, } \\
\text { Hematite }\left(\mathrm{Fe}_{2} \mathrm{O}_{3}\right)\end{array}$ & 0.79 & Berlinite $\left(\mathrm{AlPO}_{4}\right)$ & {$[44]$} \\
\hline Moncorvo, Portugal & & $0.3-0.7$ & $\begin{array}{l}\text { Apatite, Lazulite, } \\
\text { Rockbridgeite }\end{array}$ & [45] \\
\hline $\begin{array}{c}\text { Grangesberg (trade mark GR } \\
\text { 25), Sweden }\end{array}$ & 60 & 0.88 & Apatite & [46] \\
\hline $\begin{array}{c}\text { Grangesberg (high } \\
\text { phosphorus coarse fines } \\
\text { (trade mark: GRF)), Sweden }\end{array}$ & 62.73 & 0.73 & Apatite & [46] \\
\hline Kiruna, Sweden & $58-65$ & $0.5-2$ & Apatite & [46] \\
\hline $\begin{array}{c}\text { (Kiruna Ores, Sweden) } \\
\text { Lappmalmen deposit } \\
\text { Skarn-Type Ores } \\
\text { Viscaria ore }\end{array}$ & $\begin{array}{c}44.2 \\
20.4-60.9 \\
37.3-48.4\end{array}$ & $\begin{array}{c}4.30 \\
0.26-6.92 \\
0.26-1.07\end{array}$ & $\begin{array}{l}\text { Apatite } \\
\text { Apatite } \\
\text { Apatite }\end{array}$ & [47] \\
\hline
\end{tabular}

${ }^{*}$ is for average; ${ }^{* *}$ is for high-grade ore; values in [] are estimated/proven quantities of ore. 


\section{Phosphorus in Iron Ores and Theories on Its Existence in Iron Ores (Goethite).}

Phosphorus is known to have more affinity for goethite than hematite, or to be more easily associated with goethite than hematite and other iron (oxy)/hydroxides [48-53]. Goethite is the iron mineral which is most susceptible to the presence of phosphorus. Phosphorus associated with goethite ores is more likely to be present in the amorphous form, or containing significant proportions of non-crystalline phosphorus-bearing phases. Hence, it can be difficult to identify the exact phosphorus-bearing phase(s) and to dephosphorize such ores. Consequently, different theories have been advanced to account for the existence of phosphorus in goethite. The two prominent theories are the phosphorus solid-solution theory of Graham [24] and the replacement of a surface hydroxyl group by a phosphate ligand in the goethite structure theory of Morris [54] and Barbour [55], which is supported by Dukino [56]. The phosphorus solid solution theory of Graham [24] postulates that the presence of phosphorus in goethite is due to the substitution of Fe atoms by $\mathrm{P}$ atoms to form a solid solution. On the basis of significant differences in both the size of the $\mathrm{P}$ cation and charge $\left(\mathrm{P}^{\mathrm{o}}\right.$ with a charge of 0 and an atomic radius of $98 \mathrm{pm} ; \mathrm{P}^{3-}$ with a charge of -3 and ionic radius of 212 $\mathrm{pm} ; \mathrm{P}^{3+}$ with a charge of +3 and ionic radius of $44 \mathrm{pm} ; \mathrm{P}^{5+}$ with a charge of +5 and ionic radius of $17 \mathrm{pm}, 29 \mathrm{pm}$, and $48 \mathrm{pm}$, depending on coordination numbers 4, 5, and 6 respectively [57]) and the Fe cation ( $\mathrm{Fe}^{3+}$ with a charge of +3 and an ionic radius of $64.5 \mathrm{pm}$ [57]) in goethite, which does not quite satisfy the criteria [58-60] for the formation of solid solutions by atom/cation substitution, Dukino [56] argued against the plausibility of this theory. However, in a recent work, Levard et al. [61] investigated the atomic scale incorporation of Scandium (Sc) into the structure of goethite, demonstrating the formation of a solid $\alpha \mathrm{FeOOH}-\alpha \mathrm{ScOOH}$ solution. This was consistent with an ideal solution, in spite of significant differences in the atomic radii between $\mathrm{Sc}^{3+}\left(\mathrm{Sc}^{3+}\right.$ ionic radius $=74.5 \mathrm{pm}$ [57] $)$ and $\mathrm{Fe}^{3+}\left(\mathrm{Fe}^{3+}\right.$ ionic radius $\left.\left.=64.5 \mathrm{pm}[57]\right)\right)$ cations, which, at $13.4 \%$ difference, are quite close to the defined threshold values $[62,63]$ for continuous solid solutions. Levard et al. argued with some merit that, in such systems, the focus should be on the similarities in the relevant cation-oxygen bond lengths, instead of the cation sizes as percentage differences in $\mathrm{Fe}-\mathrm{O}(203 \mathrm{pm})$ and $\mathrm{Sc}-\mathrm{O}$ distance (212 pm), which is $4 \%$ closely matched observed changes in cell parameters of $3.9 \%, 3.6 \%$, and $6.1 \%$ for $a, b$, and $c$ respectively. Applying the same argument to Graham's theory [24] of Fe substitution by $\mathrm{P}$ in goethite structure, the expected difference in the $\mathrm{Fe}-\mathrm{O}(2.03 \AA[61,64,65])$ and $\mathrm{P}-\mathrm{O}$ distance differences $(\approx 153-154.8 \mathrm{pm}[64,66-70]$ in the cation-oxygen bond lengths will be in the range of 23.6-24.6\%, which are above the threshold value for the formation of a substitutional solid solution while maintaining the goethite structure; such an observation reinforces Dukino's reservations [56] about the feasibility of Graham's theory [24]. The replacement of a surface hydroxyl group by a phosphate ligand in the goethite structure theory of Morris [54] postulates that phosphorus occurs in goethite due to the replacement of surface hydroxyl groups in the goethite structure with phosphate (anion) ligand prior to the dehydration of ferrihydrite to goethite. Recently, MacRae et al. [71] proposed that for ochreous goethite, phosphorus may be incorporated into the goethite structure by a coupled substitution mechanism in which phosphorus and aluminum atoms occupy some of the sites in the ochreous goethite structure which are typically occupied by two silicon atoms.

However, looking at the upper limits of phosphorus contents reported for high-phosphorus iron ores in which distinct phosphorus minerals are yet to be identified $(0.8 \%$ [41,42] to $-1.395 \%$ [20]), with the maximum plausible substitution of Fe cations with $\mathrm{P}$ cations calculated assuming the non-plausible equality of charge, and the maximum hydroxyl ion substitution with phosphate ligand that permits the maintenance of the stability of the respective structures (in P solid solution with goethite and phosphate ligand substitution of hydroxyl groups in goethite), it might be argued that both theories may not fully account for the full range of phosphorus content in iron ores. In light of the known affinity of iron oxide/hydroxide surfaces for phosphorus/phosphate anions which permits their use as adsorbents for phosphorus removal [49,72-89], it stands to reason that a significant proportion of phosphorus in high-phosphorus iron ores, especially in goethite ores, might be present as adsorbed species on the mineral surface. This would most probably account for the typically low 
fraction of phosphorus leached out in raw or low temperature thermal-treated, high-phosphorous ores predominantly containing crystalline phases with very low solubilities in the leachant, as can be seen in some reports $[36,90,91]$. Such adsorbed phosphorus species are likely to be less difficult to remove compared to "micropore bound and mesopore bound" phosphorus $[78,92]$. In soil science and geochemistry, differences in the ease of phosphorus removal (due to its different binding phases and the resultant solubility properties) have been proposed as sequential extraction schemes [93], and have been widely employed [93-101] to classify or make speciation of the phosphorus contents of soils and target materials as total phosphorus (TP), loosely adsorbed or exchangeable phosphorus (LSP), iron-bound phosphorus $(\mathrm{Fe}-\mathrm{P})$, authigenic carbonate fluorapatite + biogenic apatite $+\mathrm{CaCO}_{3}$-associated $\mathrm{P}(\mathrm{Ca}-\mathrm{P})$, detrital apatite phosphorus + other inorganic phosphorus, and organic phosphorus, $[93,99,101,102]$. The application of such sequential extraction schemes, which hinges on the distinct reactivity of each targeted phase to a particular extractant solution [103] or a similar scheme to phosphorus in high-phosphorus iron ores, can be of some benefit. For a better appreciation of the evolution and variety of extraction schemes for determining the fractional composition of phosphorus proposed by several authors over the years, the work of Wang et al. [98], and the references therein, are recommended.

Phosphate interactions with iron oxides can lead to its incorporation into/onto these iron (oxy)hydroxides by absorption, adsorption, association, or chemisorption, or by the precipitation of phosphate as bulk compounds, though the actual mechanisms of phosphate reactions with iron oxides and oxyhydroxides are not fully understood, nor do we have a comprehensive grasp of the conditions that favor one mode of interaction over another [104]. With respect to iron ore and its associated gangue minerals, besides being present as adsorbed phases on ore surfaces or as distinct crystalline phase(s), it has been proposed that phosphorus is capable of presenting as phosphatic groups $\left[\mathrm{PO}_{4}\right]^{3-}$ in the structures of ore minerals [105], i.e., as a solid solution [106,107], by incorporation into the ore (goethite) structure by a coupled substitution mechanism between phosphorus and aluminum at the sites normally occupied by two silicon atoms [71], and by ion exchange of phosphate and hydroxyl ions on hydrated iron and aluminum oxides [55]. The absence of free cations to support phosphorus precipitation as a phosphate is reported to promote its presence as an adsorbed anionic phase in the micropores of iron oxides/oxyhydroxides (goethite) [27,31]. Phosphate adsorption onto the oxides and hydroxides of iron and aluminum has been widely seen to be mainly responsible for the inorganic fraction of phosphorus in soils $[104,108,109]$, which is a testament to the ability of phosphorus to interact with both iron ore and gangue minerals.

Phosphorus as phosphate anions is able to form crystalline phases with cations of $\mathrm{Al}, \mathrm{Ca}$, and $\mathrm{Fe}$, which are often present in ores. As an iron phosphate, phosphorus might be present in as-is, high-phosphorus iron ore, or thermally-treated ore as one of the numerous reported iron phosphate crystalline phases, e.g., $\mathrm{FePO}_{4}, \mathrm{Fe}_{3} \mathrm{PO}_{7}, \mathrm{FeP}_{3} \mathrm{O}_{9}, \mathrm{Fe}_{9} \mathrm{PO}_{12}, \mathrm{Fe}_{4} \mathrm{P}_{6} \mathrm{O}_{21}, \mathrm{Fe}_{2} \mathrm{PO}_{5}$, $\mathrm{Fe}_{7} \mathrm{P}_{6} \mathrm{O}_{24}, \mathrm{Fe}_{3}\left(\mathrm{PO}_{4}\right)_{2}, \mathrm{Fe}\left(\mathrm{PO}_{3}\right)_{3}, \mathrm{Fe}_{2} \mathrm{P}_{2} \mathrm{O}_{7}, \mathrm{Fe}\left(\mathrm{PO}_{3}\right)_{3}, \mathrm{Fe}_{4}\left(\mathrm{PO}_{4}\right)_{2} \mathrm{O}, \mathrm{Fe}_{3}\left(\mathrm{PO}_{4}\right) 2.8 \mathrm{H}_{2} \mathrm{O}$, or strengite $\mathrm{Fe}^{3+}\left(\mathrm{PO}_{4}\right) \cdot 2\left(\mathrm{H}_{2} \mathrm{O}\right)$ [110-130]. As aluminum phosphate, phosphorus might be present in as-is, high-phosphorus iron ore as $\mathrm{AlPO}_{4}$ (berlinite) [44], Gorceixite $\left(\mathrm{BaAl}_{3}\left(\mathrm{PO}_{4}\right)_{2}(\mathrm{OH})_{5} \cdot \mathrm{H}_{2} \mathrm{O}\right)$, Lazulite $((\mathrm{Mg}$, $\left.\left.\mathrm{Fe}^{2+}\right) \mathrm{Al}_{2}\left(\mathrm{PO}_{4}\right)_{2}(\mathrm{OH})_{2}\right)$, Senegalite $\left(\mathrm{Al}_{2}\left(\mathrm{PO}_{4}\right)(\mathrm{OH})_{3} \cdot \mathrm{H}_{2} \mathrm{O}\right)$, Turquoise $\left(\mathrm{CuAl}_{6}\left(\mathrm{PO}_{4}\right)_{4}(\mathrm{OH})_{8} \cdot 5\left(\mathrm{H}_{2} \mathrm{O}\right)\right)$, Wardite $\left(\mathrm{NaAl}_{3}\left(\mathrm{PO}_{4}\right)_{2}(\mathrm{OH})_{4} \cdot 2\left(\mathrm{H}_{2} \mathrm{O}\right)\right)$, or Wavellite $\left(\mathrm{Al}_{3}\left(\mathrm{PO}_{4}\right)_{2}(\mathrm{OH})_{3} \cdot 5\left(\mathrm{H}_{2} \mathrm{O}\right)\right)$ (see Table 1). As a calcium phosphate, phosphorus might be present in high-phosphorus iron ore as apatite $\left(\mathrm{Ca}_{5}\left(\mathrm{PO}_{4}\right)(\mathrm{F}, \mathrm{Cl}\right.$, $\mathrm{OH})$ ) [23,24] or Crandallite $\left(\mathrm{CaAl}_{3}\left(\mathrm{PO}_{4}\right)_{2}(\mathrm{OH})_{5} .\left(\mathrm{H}_{2} \mathrm{O}\right)\right)$ [27-29]. Table 1 presents most of the reported crystalline presentations of phosphorus in high-phosphorus iron ores. Though the challenges (i.e., the validity of a measured mass solubility and assumed solution speciation) and consequent accuracy issues in the determination of solubility products (Ksp) of some phosphate systems have been highlighted by Pan and Darvell [131], the respective solubility data (solubility products) for a variety of phosphorus-containing minerals (crystalline phases) that can be associated with high phosphorus, and thus might be useful in designing hydrometallurgical phosphorus removal/recovery strategies, are presented in Table 2. 
Table 2. Solubility data for some phosphate phases.

\begin{tabular}{|c|c|c|c|}
\hline P Presentation (Name) & Chemical Formula & Solubility Product $\left(K_{s p}\right)$ & Ref \\
\hline Apatite & $\mathrm{Ca}_{5}\left(\mathrm{PO}_{4}\right)(\mathrm{F}, \mathrm{Cl}, \mathrm{OH})$ & & \\
\hline Chlorapatite & $\mathrm{Ca}_{5}\left(\mathrm{PO}_{4}\right)_{3} \mathrm{Cl}$ & $10^{-53.08}$ & [132] \\
\hline Fluorapatite & $\mathrm{Ca}_{5}\left(\mathrm{PO}_{4}\right)_{3} \mathrm{~F}$ & $\begin{array}{c}8.6 \pm 1.3 \times 10^{-61} \\
3.19 \pm 0.14 \times 10^{-61}\end{array}$ & $\begin{array}{l}{[133]} \\
{[134]}\end{array}$ \\
\hline Hydroxyapatite & $\mathrm{Ca}_{5}\left(\mathrm{PO}_{4}\right)_{3} \mathrm{OH}$ & $\begin{array}{c}0.53 \text { to } 7.59 \times 10^{-58} \\
2.91 \times 10^{-58} \\
4.7 \times 10^{-59} \\
7.2 \times 10^{-53} \text { to } 6.4 \times 10^{-58} \\
4.8 \times 10^{-59} \\
10^{-57} \\
7.36 \pm 0.93 \times 10^{-60} \\
10^{-56.02}\end{array}$ & $\begin{array}{c}{[135]} \\
{[136]} \\
{[137]} \\
{[138]} \\
{[139-141]} \\
{[142]} \\
{[134]} \\
{[143]}\end{array}$ \\
\hline TCP & $\mathrm{Ca}_{3}\left(\mathrm{PO}_{4}\right)_{2}$ & $1.20 \times 10^{-29}$ & [144] \\
\hline $\mathrm{OCP}$ & $\mathrm{Ca}_{8} \mathrm{H}_{2}\left(\mathrm{PO}_{4}\right)_{6} \cdot 5 \mathrm{H}_{2} \mathrm{O}$ & $1.06 \times 10^{-47}$ & [145] \\
\hline Monetite (DCPA) & $\mathrm{CaHPO}_{4}$ & $\begin{array}{c}1.26 \times 10^{-7} \\
0.92 \text { to } 1.97 \times 10^{-7} \\
10^{-6.60}\end{array}$ & $\begin{array}{l}{[146]} \\
{[147]} \\
{[143]}\end{array}$ \\
\hline $\begin{array}{c}\text { Brushite } \\
\text { (DCPD or dicalcium } \\
\text { phosphate dihydrate) }\end{array}$ & $\mathrm{CaHPO}_{4} \cdot 2 \mathrm{H}_{2} \mathrm{O}$ & $\begin{array}{c}2.49 \times 10^{-7} \\
2.59 \times 10^{-7} \\
2.77 \times 10^{-7} \\
2.7 \times 10^{-7} \\
10^{-6.60}\end{array}$ & $\begin{array}{l}{[148]} \\
{[149]} \\
{[150]} \\
{[151]} \\
{[143]}\end{array}$ \\
\hline \multirow[t]{2}{*}{$\beta$-Tricalcium Phosphate } & $\beta-\mathrm{Ca}_{3}\left(\mathrm{PO}_{4}\right)_{2}$ & $\begin{array}{c}1.38 \times 10^{-29} \\
10^{-30.74}\end{array}$ & $\begin{array}{l}{[152]} \\
{[143]}\end{array}$ \\
\hline & $\mathrm{Ca}_{3}\left(\mathrm{PO}_{4}\right)_{2}$ & $2.07 \times 10^{-33}$ & [153] \\
\hline \multirow[t]{2}{*}{ Berlinite } & $\mathrm{AlPO}_{4}$ & $9.84 \times 10^{-21}$ & [153] \\
\hline & $\mathrm{FePO}_{4}$ & $\begin{array}{c}10^{-22} \\
10^{-22.8} \text { to } 10^{-24.6}\end{array}$ & $\begin{array}{l}{[154]} \\
{[155]}\end{array}$ \\
\hline Ferrous Phosphate & $\mathrm{Fe}_{3}\left(\mathrm{PO}_{4}\right)_{2}$ & $1.3 \times 10^{-30}$ & [156] \\
\hline Strengite & $\mathrm{Fe}^{3+}\left(\mathrm{PO}_{4}\right) \cdot 2\left(\mathrm{H}_{2} \mathrm{O}\right)$ & $\begin{array}{c}10^{-34.9 \pm 0.1} \\
10^{-34.3} \\
10^{-33.6} \text { to } 10^{-35.1}\end{array}$ & $\begin{array}{l}{[157]} \\
{[158]} \\
{[159]}\end{array}$ \\
\hline vivianite & $\left(\mathrm{Fe}_{3}\left(\mathrm{PO}_{4}\right)_{2} \cdot 8 \mathrm{H}_{2} \mathrm{O}\right)$ & $\begin{array}{c}10^{-35.755} \\
10^{-36 \pm 0.1} \\
10^{-40} \\
1.07 \times 10^{-29}\end{array}$ & $\begin{array}{l}{[160]} \\
{[161]} \\
{[162]} \\
{[163]}\end{array}$ \\
\hline Variscite & $\mathrm{Al}\left(\mathrm{PO}_{4}\right) \cdot 2\left(\mathrm{H}_{2} \mathrm{O}\right)$ & $\begin{array}{c}10^{-30.5} \\
10^{-28.06 \pm 0.05} \\
10^{-30.5}\end{array}$ & $\begin{array}{l}{[164]} \\
{[165]} \\
{[158]}\end{array}$ \\
\hline xenotime & $\mathrm{YPO}_{4}$ & $10^{-24.76}$ & [166] \\
\hline Whitlockite & $\mathrm{Ca}_{9} \mathrm{Mg}\left(\mathrm{HPO}_{4}\right)\left(\mathrm{PO}_{4}\right)_{6}$ & $\begin{array}{c}10^{-113.75 \pm 2.18} \\
10^{-109.48} \\
10^{-29.53 *} \\
10^{-29.9} \text { to } 10^{-33.5 *}\end{array}$ & $\begin{array}{l}{[167]} \\
{[168]} \\
{[143]} \\
{[169]}\end{array}$ \\
\hline Allanpringite & $\mathrm{Fe}_{3}\left(\mathrm{PO}_{4}\right)_{2}(\mathrm{OH})_{3} \cdot 5 \mathrm{H}_{2} \mathrm{O}$ & NA & \\
\hline Barrandite & $(\mathrm{Al}, \mathrm{Fe}) \mathrm{PO}_{4} \cdot 2\left(\mathrm{H}_{2} \mathrm{O}\right)$ & NA & \\
\hline Crandallite & $\mathrm{CaAl}_{3}\left(\mathrm{PO}_{4}\right)_{2}(\mathrm{OH})_{5}\left(\mathrm{H}_{2} \mathrm{O}\right)$ & NA & \\
\hline
\end{tabular}


Table 2. Cont.

\begin{tabular}{|c|c|c|c|}
\hline P Presentation (Name) & Chemical Formula & y Product $\left(K_{\mathrm{sp}}\right)$ & Ref \\
\hline Frondelite & $\mathrm{Mn}^{2+} \mathrm{Fe}^{3+} 4\left(\mathrm{PO}_{4}\right)_{3}(\mathrm{OH})_{5}$ & NA & \\
\hline Gorceixite & $\mathrm{BaAl}_{3}\left(\mathrm{PO}_{4}\right)_{2}(\mathrm{OH})_{5} \cdot \mathrm{H}_{2} \mathrm{O}$ & NA & \\
\hline Giniite & $\mathrm{Fe}^{2+} \mathrm{Fe}^{3+}{ }_{4}\left(\mathrm{PO}_{4}\right)_{4}(\mathrm{OH})_{2} \cdot 2\left(\mathrm{H}_{2} \mathrm{O}\right)$ & NA & \\
\hline Lazulite & $\left(\mathrm{Mg}, \mathrm{Fe}^{2+}\right) \mathrm{Al}_{2}\left(\mathrm{PO}_{4}\right)_{2}(\mathrm{OH})_{2}$ & NA & \\
\hline monazite & $(\mathrm{Ce}, \mathrm{La}, \mathrm{Y}, \mathrm{Th}) \mathrm{PO}_{4}$ & $\begin{array}{l}3 \text { for } \mathrm{NdPO}_{4} \\
{ }^{7} \text { for } \mathrm{GdPO}_{4}\end{array}$ & [170] \\
\hline Rockbridgeite & $\mathrm{Fe}^{2+} 0.75 \mathrm{Mn}^{2+} 0.25 \mathrm{Fe}^{3+} 4\left(\mathrm{PO}_{4}\right)_{3}(\mathrm{OH})_{5}$ & NA & \\
\hline Senegalite & $\mathrm{Al}_{2}\left(\mathrm{PO}_{4}\right)(\mathrm{OH})_{3} \cdot \mathrm{H}_{2} \mathrm{O}$ & NA & \\
\hline Turquoise & $\mathrm{CuAl}_{6}\left(\mathrm{PO}_{4}\right)_{4}(\mathrm{OH})_{8} \cdot 5\left(\mathrm{H}_{2} \mathrm{O}\right)$ & NA & \\
\hline Wardite & $\mathrm{NaAl}_{3}\left(\mathrm{PO}_{4}\right)_{2}(\mathrm{OH})_{4} \cdot 2\left(\mathrm{H}_{2} \mathrm{O}\right)$ & NA & \\
\hline Wavellite & $\mathrm{Al}_{3}\left(\mathrm{PO}_{4}\right)_{2}(\mathrm{OH})_{3} \cdot 5\left(\mathrm{H}_{2} \mathrm{O}\right)$ & NA & \\
\hline
\end{tabular}

\section{Reactivity of Phosphorus towards Some Mineral Surfaces and Factors Exerting Influence(s) on Phosphorus Reactivity}

Phosphorus as organic esters of phosphoric acids or as inorganic phosphates exhibits a high reactivity to environmental particles [171], including mineral surfaces. This phenomenon is attributed to the high stability of phosphate surface complexes and the tendency to form insoluble compounds with ubiquitous metal ions [172]. Consequently, any factors affecting phosphate formation and the stability of its surface complexes with mineral surfaces and formation/precipitation of insoluble compounds onto mineral surfaces, will be critical to phosphorus association with minerals, and to the development of strategies for phosphorus removal/recovery. A principal route of phosphorus interaction with minerals is by adsorption to mineral surfaces.

Phosphorus adsorption on mineral (iron oxide) surfaces can be affected by a variety of factors and to varying degrees. The ionic strength of the media is reported to exert a quite minor effect on phosphorus adsorption onto the surface of goethite [173], which had been interpreted as being indicative of limited competition between phosphorus and the electrolyte ions for adsorption sites on the surface of goethite [174]. Besides ionic strength, other factors capable of influencing phosphorus adsorption on iron oxide surface include $\mathrm{pH}[79,173,175-178]$, the crystallinity and morphology of the mineral [179-182], competition between the phosphate anion and other anions for adsorption sites on mineral surface [176,183-190], time [83], charge on minerals [191], the presence of ligands [191], temperature [192], exposed crystal habit (face) [193], and the porosity of the oxide [194].

Ahmed et al. [178] studied the competitive chemical adsorption of phosphate, water, and $\mathrm{OH}^{-}$ onto the surface of goethite via covalent bonds, and ranked their respective propensities to adsorb to the surface of goethite as follows: $\mathrm{H}_{2} \mathrm{O}>$ phosphate $>\mathrm{OH}^{-}$. This ranking indicates that $\mathrm{OH}^{-}$ions are able to displace phosphate anions from the surface of goethites, which is in agreement with earlier reports of phosphorus desorption from the surface of goethite and/or reduced adsorption at high $\mathrm{pH}$ (abundance of $\mathrm{OH}^{-}$) $[173,175]$, suggesting that the phosphorus fraction in high-phosphorus iron ores due to phosphate adsorption to mineral surface might be amenable to removal by alkaline leaching.

\section{Theories on Phosphate Adsorption to Mineral (Iron Oxide) Surfaces}

Phosphates can be attached to mineral (goethite) surfaces by adsorption $[50,187]$ or by surface precipitation [195-199].

There is consensus among researchers that phosphate adsorption onto iron (hydr)oxide surfaces occurs via the formation of inner-sphere surface complexes, with the adsorbing species forming 
Fe-O-P bonds with Fe cations (Figure 1) [184,200-203]; however, there are diverse opinions on the predominating P-laden surface complexes/species (Table 3). Since in aqueous media, the surfaces of iron (hydr)oxides can contain other adsorbed species or ligands such as water molecules or hydroxyl ions, arsenate, glyphosate, etc., phosphate adsorption is perceived to occur by ligand-exchange or ligand-substitution reaction, in which the incoming ligand, phosphate, displaces the already-adsorbed ligand, promoting an undesired desorption [186,203-205].
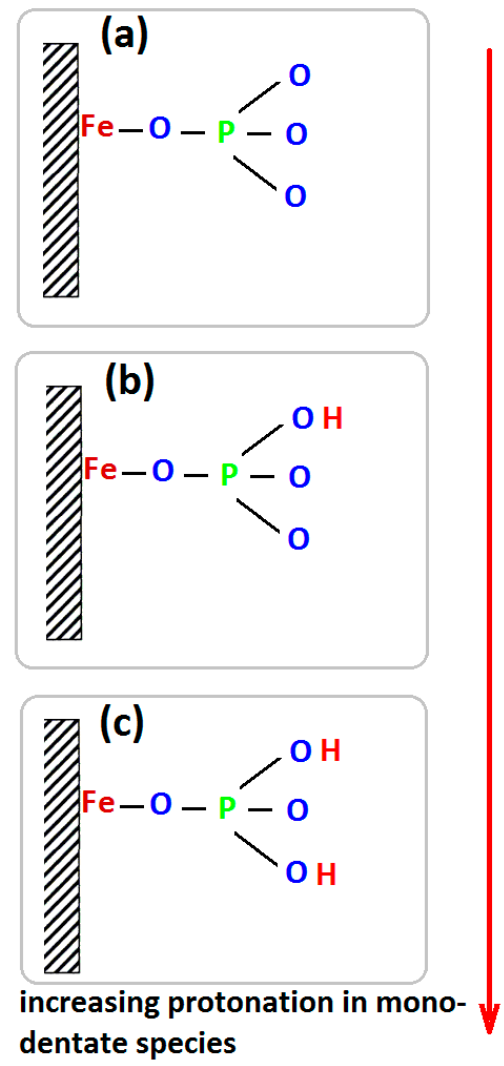
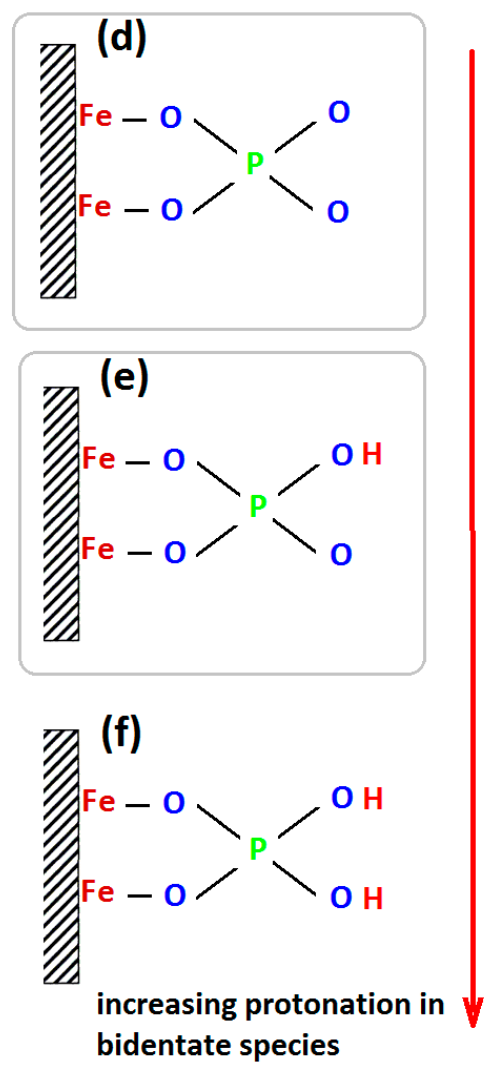

Figure 1. Illustration of plausible phosphate surface complexes at the interface with iron (oxy)hydroxides; (a) mono-dentate unprotonated, (b) mono-dentate mono-protonated, (c) mono-dentate bi-protonated, (d) bi-dentate unprotonated, (e) bi-dentate mono-protonated, and (f) bi-dentate bi-protonated (encircled in gray boxes are the predominant species reported in published literature (Table 3).

Different theories have been advanced to explain phosphate adsorption to oxide/oxyhydroxide mineral surfaces and the observed biphasic phosphate adsorption/desorption kinetics. Knowledge on the precise phosphate species adsorbed onto Fe oxide surfaces, the binding ligand type(s) (monodentate, bidentate) and their respective predominances, with respect to different relevant variables such as $\mathrm{pH}$, phosphate binding sites on mineral surfaces, effect of crystal faces, and phosphate binding mechanism(s) to the mineral surfaces, is evolving with an apparent lack of consensus regarding the interpretation of some observations, principally the dominant surface complex(es)/species at different $\mathrm{pH}$ and phosphate loadings [84,172,174,200-203,206,207]. Whereas the earlier work of Tejedor-Tejedor and Anderson [200] proposed that both monodentate and bidentate complexes are formed on the surface of goethite at different pHs, subsequent works by Persson et al. [201] and Arai and Sparks [207] have proposed protonated monodentate complexation of phosphates with goethite at $\mathrm{pH} 7.9$, and deprotonated bidentate complexation with ferrihydrite at $\mathrm{pH} 7.5$.

In an attempt to resolve the controversy about phosphate surface complexes on iron hydroxide surfaces, Kwon and Kubicki [84] employed quantum mechanical calculations of the adsorption energies and infrared (IR) spectra of six possible surface complexes (deprotonated, monoprotonated, 
and diprotonated versions of bridging bidentate and monodentate complexes), and reported four possible surface complexes (species) that change depending on $\mathrm{pH}$, i.e., a diprotonated bidentate complex at $\mathrm{pH} 4-6$, a deprotonated bidentate, or a monoprotonated monodentate complex at $\mathrm{pH}$ 7.5-7.9, and a deprotonated monodentate complex at $\mathrm{pH}$ 12.8. They also reported [84] that the stability of the monoprotonated monodentate complex is favored, based on reaction energy calculations for adsorption from aqueous solution. In a recent work, Arroyave et al. [203] employed a new spectroscopic technique, Infrared Surface Titrations (IRST), to study the surface speciation of phosphate on goethite in a $\mathrm{pH}$ range of 4.5-9.5 at different surface coverages. They reported that this technique is able to detect adsorbed phosphate species, and that two monodentate phosphate complexes (mononuclear monoprotonated and mononuclear diprotonated species) are present on the surface of goethite. They also reported that the ratios of these two species varies with changes in $\mathrm{pH}$ and surface coverage. Their results [203] indicated that at low surface coverage $\left(0.7 \mu \mathrm{mol} \cdot \mathrm{m}^{-2}\right)$, the mononuclear monoprotonated species prevail through all of the $\mathrm{pH}$ range studied, while at high surface coverage $\left(2.0 \mu \mathrm{mol} \cdot \mathrm{m}^{-2}\right)$, mononuclear diprotonated species predominate at $\mathrm{pH}<5.5$, and mononuclear monoprotonated species predominate at $\mathrm{pH}>5.5$.

Table 3. Comparison of reports on predominant P-laden species on (oxy) hydroxide surfaces.

\begin{tabular}{|c|c|c|c|}
\hline Reported Predominant Species & Condition & Substrate & Ref \\
\hline $\begin{array}{l}\text { monodentate monoprotonated } \\
\text { species, either }(\mathrm{FeO}),(\mathrm{OH}) \mathrm{PO} \text { or } \\
(\mathrm{FeO})(\mathrm{OH}), \mathrm{PO} .\end{array}$ & $\mathrm{pH} 1.3$ to 13.5 & Goethite & [200] \\
\hline $\begin{array}{c}\text { three monodentate surface } \\
\text { complexes; }=\mathrm{FePO}_{4}=\mathrm{FePO}_{4} \mathrm{H}^{-} \\
\text {and }=\mathrm{FePO}_{4} \mathrm{H}_{2}\end{array}$ & $\mathrm{pH} 3$ to 9 & Goethite & [208] \\
\hline $\begin{array}{l}\text { monodentate coordinated } \\
\text { complexes }\end{array}$ & pH 1.1 to 13 & Goethite & [201] \\
\hline $\begin{array}{c}\text { non-protonated bidentate } \\
\text { binuclear species }\left(\mathrm{Fe}_{2} \mathrm{PO}_{4}\right) \\
\text { [protonated complexes forming at } \\
\text { pH } 7.5 \text { could not be determined } \\
\text { due to limitations in mid-IR range, } \\
\text { FTIR analysis] }\end{array}$ & $\begin{array}{l}\text { (at } \mathrm{pH} \geq 7.5) \\
(\text { at } \mathrm{pH}<7.5)\end{array}$ & ferrihydrite & [207] \\
\hline $\begin{array}{c}\text { bidentate non-protonated } \\
(\mathrm{FeO})_{2} \mathrm{PO}_{2} \text { and bidentate } \\
\text { protonated }(\mathrm{FeO})_{2}(\mathrm{OH}) \mathrm{PO} \\
\text { complexes } \\
\text { bidentate nonprotonated } \\
(\mathrm{FeO})_{2} \mathrm{PO}_{2} \text {, and an extra } \\
\text { unidentified species at low } \\
\text { concentration }\end{array}$ & at $\mathrm{pH} 7.5$ and 9 & Goethite & [174] \\
\hline $\begin{array}{l}\text { change from monodentate } \\
\text { complexation to bidentate } \\
\text { complexation with increasing } \\
\text { surface phosphate coverage. } \\
\text { protonated bidentate species } \\
(\mathrm{FeO})_{2} \mathrm{PO}_{2} \mathrm{H}^{-} \\
\text {protonated bidentate species } \\
(\mathrm{FeO})_{2} \mathrm{PO}_{2} \mathrm{H}^{-} \\
\text {With the increase in pH values, } \\
\text { bidentate phosphate species } \\
(\mathrm{FeO})_{2} \mathrm{PO}_{2} \mathrm{H}^{-} \text {undergo } \\
\text { deprotonation reaction yielding } \\
\text { unprotonated species } \\
(\mathrm{FeO})_{2} \mathrm{PO}_{2}{ }^{-2} \text {. }\end{array}$ & $\begin{array}{l}\text { at } \mathrm{pH} 3.5 \\
\text { at } \mathrm{pH} 4.7\end{array}$ & Goethite & [209] \\
\hline
\end{tabular}


Table 3. Cont.

\begin{tabular}{|c|c|c|c|}
\hline Reported Predominant Species & Condition & Substrate & Ref \\
\hline $\begin{array}{l}\text { bidentate surface complexes; } \\
\mathrm{Fe}_{2} \mathrm{O}_{2} \mathrm{PO}_{2} \text {, and } \mathrm{Fe}_{2} \mathrm{O}_{2} \mathrm{POOH} \\
\text { and presence of non-protonated } \\
\text { monodentate surface complexes; } \\
\text { FeOPO } \mathrm{O}_{3} \text { only at high pH }\end{array}$ & $\begin{array}{l}\mathrm{pH} 4 \text { to } 10 \\
\mathrm{pH}>9.8\end{array}$ & Ferrihydrite & [210] \\
\hline $\begin{array}{l}\text { binding via binuclear bidentate } \\
\text { complexation (i.e., binding of two } \\
\text { phosphate oxygen atoms to two } \\
\text { adjacent } \mathrm{Fe}^{3+} \text { surface sites) } \\
\text { predominate }\end{array}$ & $\mathrm{pH} 3$ to 11 & $\begin{array}{c}\text { On goethite } \\
\text { (a-FeOOH), } \\
\text { akaganeite } \\
\text { (b-FeOOH), } \\
\text { and lepidocrocite } \\
\text { (g-FeOOH) }\end{array}$ & [50] \\
\hline $\begin{array}{c}\text { double or triple-protonated } \\
\text { phosphate ions on ferrihydrite } \\
\text { and goethite } \\
\text { existence of double- and } \\
\text { single-protonated phosphate } \\
\text { species due to deprotonation of } \\
\text { adsorbed phosphate } \\
\text { diprotonated phosphate desorbed } \\
\text { faster than monoprotonated } \\
\text { phosphate }\end{array}$ & at $\mathrm{pH} 4$ & $\begin{array}{c}\text { Ferrihydrite and } \\
\text { Goethite }\end{array}$ & [172] \\
\hline $\begin{array}{l}\text { mononuclear monoprotonated } \\
\text { species } \\
\text { mononuclear diprotonated species } \\
\text { mononuclear monoprotonated } \\
\text { species }\end{array}$ & $\begin{array}{c}\text { at } \mathrm{pH}>5.5 \\
\text { at } \mathrm{pH}<5.5 \\
\text { at all } \mathrm{pH} \\
\text { (at low surface coverage) }\end{array}$ & Goethite & [203] \\
\hline
\end{tabular}

\section{Factors Influencing Phosphate Adsorption to Mineral (Iron Oxide) Surfaces}

Factors which are capable of influencing phosphorus adsorption on iron oxide (goethite) surface include $\mathrm{pH}[173,175-177]$, ionic strength [173], the crystallinity and morphology of goethite [79,179-182], competition between phosphate anion and other anions for adsorption sites on the surface of goethite [176,183-190], time [83], crystal faces present on mineral surfaces [193,211], and the point of zero charge (PZC), which is reported to be in the range of 7.4-9.6 for goethite (a-FeOOH) [212-217], 4.8-8.0 for lepidocrocite [50,218-220], 4.80-8.68 for hematite [221,222], 4.2-7.1 for magnetite [222,223], 6.3-7.5 for maghemite [213,224,225], between 5.3 and 7.5 for natural ferrihydrites [222,226], 2.8-5 for kaolinite [214,227,228], 5-9.6 for alumina [223,229,230], 9.5-10.6 for akaganeite [230,231], and $2-4$ for quartz $[223,229,231-233]$.

Besides its ability to bind to iron mineral surfaces, phosphate is able to bind to other mineral surfaces such as kaolinite [234], silicates [235-239], and clay minerals [240-244], which are often present in iron ores as associated gangue minerals.

\section{Plausible Reasons for Differences in the Ease of Phosphorus Removal from Different Iron Ores}

Differences exist in the ease of phosphorus removal from different iron ores using the same procedures. Jin et al. [36] employed alkali-leaching (using sodium hydroxide) and acid-leaching (using sulfuric, hydrochloric, and nitric acids) to dephosphorize Changde iron ore (China) containing about $1.12 \%$ P. Using this method, they reported success in the removal of the phosphorus fraction, presenting as apatite with alkaline leaching, but failure in the removal of the phosphorus fraction that was not apatite. From this report, a question arises: What are the reasons for the ease of $P$ removal with alkaline leaching when phosphorus presents as apatite? From the literature, phosphorus presentation has been shown to influence the degree of success of P removal [42]; clarification of the reason(s) for such a phenomenon is therefore needed. The answers to this question are most probably linked to differences in the solubility of the different phosphate containing phases in the different leaching solutions and the effects of prior thermal treatments on the solubility of the succeeding or resultant 
phosphate-laden phase(s). This explanation finds support in a much earlier report by Hertzog [245] that stated that while calcium, manganese, and ferrous phosphates were soluble in inorganic acids (such as hydrochloric, sulfuric, and nitric acids) and organic acids (such as oxalic, citric, tartaric, and acetic acids), aluminum and ferric phosphates were not. However, aluminum and ferrous phosphates had high solubilities in alkaline media (e.g., sodium hydroxide and potassium hydroxide). Furthermore, he reported [245] that upon heating the minerals to $650{ }^{\circ} \mathrm{C}$ for 15 minutes, some changes in solubility occurred, i.e., the heated "ferrous and manganese phosphates" ceased to be soluble in nitric acid, while the solubility of calcium phosphate in the minerals acids was unaffected. Hertzog attributed the marked change in the solubility of the ferrous phosphate to its conversion to the less soluble ferric phosphate [42]. Table 2 presents the solubility data for a wide range of phosphate-rich phases associated with iron ores. From Table 2, it is evident that there is a dearth of solubility data for relevant complex (multi-cation) phosphorus-containing minerals like barrandite, crandallite, frondelite, gorceixite, giniite, lazulite, monazite, rockbridgeite, senegalite, turquoise, wardite, and wavellite, which are often associated with high-P iron ores. An analysis of the solubility information of 646 minerals [246] in water and concentrated mineral acids $\left(\mathrm{HCl}, \mathrm{HNO}_{3}, \mathrm{H}_{2} \mathrm{SO}_{4}\right.$, and $\mathrm{HF}$ ) indicates that iron oxide minerals (hematite and goethite) and many relevant phosphorus-containing minerals (collophane, variscite, vivianite, fluorapatite, strengite, and wavellite) are soluble in $\mathrm{HCl}$ but not in other test media (water, concentrated $\mathrm{HNO}_{3}$, and $\mathrm{H}_{2} \mathrm{SO}_{4}$ ). This trend has implications on the choice of acid, the magnitude of iron loss, and the phosphorus removal efficiency in the acid leaching of high-P iron ores. The leaching of high-P iron ores containing phosphorus-laden minerals with low solubilities in the leach solution without prior treatment to transform these minerals into more soluble phases is likely to yield limited success. Hence appreciation of the solubility properties of the phosphorus-containing minerals in each high-P iron ore is crucial to the development of phosphorus removal/recovery solutions suitable to particular high-P iron ores. From these, it obvious that adequate knowledge of the presentations of phosphorus in particular high-phosphorus iron ore(s), and the physicochemical properties of the present phase(s), is vital to the development of effective phosphorus removal schemes.

Besides iron content, phosphorus content, and the presentation of iron in the ores, other important factors that might account for this are the composition of the gangue associated with the respective ores, their distribution, and their respective abilities to adsorb phosphorus compared to the iron-containing phase of the ores. It is well known that marked differences exist in the ability of different iron oxides and oxyhydoxides to adsorb phosphate, and in the kinetics of the adsorption processes [50,79,83,85,247-252], which has been linked to differences in their respective surface properties and mineralogy [253]. The most reported order is goethite $>$ hematite $>$ ferrihydrite $[79,254,255]$, while phosphate desorption kinetics (in percentage of prior adsorbed phosphate desorbed) are ranked as follows: hematite $(12.5 \%)$ $>$ goethite $(10 \%)>$ ferrihydrite (8.5\%) [79]. Ruan and Gilkes [256] studied the phosphate sorption and desorption kinetics by synthetic aluminous goethite and their dehydroxylated products after thermal transformation. They reported that most of the adsorbed phosphate was present at the crystal surfaces, and that phosphate sorption increased with equilibrium solution concentration, increased aluminum substitution, and surface area, but decreased with increasing crystal size, and that the order of phosphate adsorption was as follows: partially-dehydroxylated goethite $\left(\approx 220^{\circ} \mathrm{C}\right)>$ hematite $\left(\geq 260^{\circ} \mathrm{C}\right)>$ goethite $\left(<110^{\circ} \mathrm{C}\right)$. They [256] attributed the observed trend to the emergence of a high-surface-area, microporous mixture comprised of goethite and hematite of small mean crystal size and with structural defects such as voids. This report suggests that the thermal treatment of iron ores can influence their interaction with phosphate. On the other hand, iron ores are known to be associated with various other phases like kaolinite, as in the Agbaja ore from Nigeria [20], dolomite, clinochlore, and quartz, as in the ore from Hubei province (China) [257], kaolinite, as in the ore from Pilbara area of Western Australia [258], quartz and chamosite as in the ore from Aswan area of Egypt [38], clay-like minerals such as carbonates, chlorite, other aluminosilicates, and quartz as in the ore from Lisakovsk, North Kazakhstan [41,107], and silica and alumina, as in the ore from Moncorvo in north-east Portugal [45,259-261]. Wei et al. [234] studied the surface properties and phosphate 
adsorption of goethite, kaolinite, goethite-kaolinite association (GKA) and goethite-kaolinite mixture (GKM), and established their respective $\mathrm{pHs}$ at a point of zero charge (PZC) to be around 8.2, 4.1, 7.0, and 6.1 respectively, and their surface charges at $\mathrm{pH} 5$ to be $0.561,-0.092,0.097$, and $0.041 \mathrm{mmol} / \mathrm{g}$, respectively. They concluded that in comparison to the adsorption capacities of goethite and kaolinite, their combinations (goethite-kaolinite association (GKA) and goethite-kaolinite mixture (GKM)) were more effective phosphate adsorbents, with the phosphate adsorption capacity of GKA being markedly higher than that of GKM. Hence, when the associated gangue has similar phosphorus adsorption abilities to the iron-rich phase (as in the Agbaja iron ore [20]), goethite; phosphorus removal can be quite challenging. In such scenarios, repartition of the associated phosphorus from the iron-rich phase to the gangue phase by chemical processing is quite difficult without a prior thermal treatment to manipulate the phases present in the ore. In such a case, the aim should be to achieve phase transformation of the iron-rich phase at the lowest energy cost and time duration into a phase that is much less accommodating of phosphorus and preferably magnetic. This can make magnetic separation feasible, whilst transforming the gangue to a more phosphorus accommodating and non-magnetic phase. These criteria, especially with respect to low thermal treatment times at lower energy inputs, are most likely to be satisfied by microwave thermal treatment of ores. This is currently a subject of much research interest [262-266]. Consequently, success in the efficient removal of phosphorus from high-phosphorus iron ores is most likely to be favored by the development of phosphorus removal strategies suited to particular high-phosphorus iron ores (or closely-related ores based on composition), instead of a global solution.

\section{Recent Efforts at Phosphorus Removal from Different High-P Iron Ores}

Thermal processing of high-phosphorus iron ores in phosphorus removal strategies prior to their use for steel making is an energy intensive step with huge economic and environmental implications. Hence, a sustainable solution for phosphorus recovery from high-phosphorus iron ores should aim to obviate this step, or, as much as possible, to reduce the required energy input. Since thermal treatment alone does not appear to be a viable phosphorus removal solution without a subsequent leaching step for most high-phosphorus iron ores, the desirable properties of an ideal, sustainable, and economic leachant for phosphorus removal and recovery from are highlighted. An ideal leachant must be cheap, abundant, readily available, easy to handle, and able to solubilize as much phosphorus as possible in solution whilst dissolving little iron. It must also be suitable for phosphorus removal either by precipitation, coagulation, or electrochemical techniques, with minimal material and/or energy input. Furthermore, it should be amenable to regeneration, so it can be used continuously.

With respect to cost and environmental concerns, the desirable conditions for phosphorus removal from high-phosphorus iron ores by hydrometallurgical processing include the use of a cheap, environmentally-benign leachant (preferably water), low leaching temperature and leaching time, high phosphorus removal rates with minimal iron loss, and the recyclability of leachant. Though not considered as economically viable or environmentally friendly as hydrometallurgical processes, the conditions desirable for the thermal processing of high-phosphorus iron ores for phosphorus removal without subsequent leaching are optimized thermal treatment procedures (temperature, time, and additives) that ensure the conversion of the phosphorus present to a phase that can be separated by some physical means or which is more amenable to leaching, when a subsequent process is desired. Against the background of such stringent requirements, recent literature reports on leaching shall be briefly reviewed and arbitrarily classified into three $\mathrm{pH}$ regimes: acidic $(\mathrm{pH} \approx 0-4)$, neutral or near-neutral $(\mathrm{pH} \approx \geq 4-8)$, and alkaline $(\mathrm{pH} \approx \geq 8-14)$.

Jin et al. [36] employed both acid leaching and alkaline leaching (with $1 \mathrm{M} \mathrm{NaOH}$ ) on Changde iron ore, i.e., a hematite ore with a total P content of $1.12 \%$, and with $22.3 \%$ of the $\mathrm{P}$ content occurring as apatite, $67.9 \%$ associated with the iron phase, and $9.8 \%$ in the silicate phase. They reported the removal of only $27.9 \%$ of the $\mathrm{P}$ content. On the basis of their results, they concluded that alkaline leaching is ineffective for phosphorus removal, and, attributing the fraction of phosphorus they removed to 
that in the apatite phase, posited that phosphorus occurring as apatite phase is amenable to removal by alkaline leaching, while that occurring in the iron phase is not [36]. This report highlights the importance of the presentation of phosphorus in the development of phosphorus removal strategies.

Fisher-White et al. [258], working on Australian iron ores principally comprised of goethite, hematite, magnetite, and kaolinite, and with P contents in the range of 0.123 to $0.161 \% \mathrm{P}$, reported similar $P$ removal rates, i.e., $27.1 \%$, by the alkaline leaching (with $5 \mathrm{M} \mathrm{NaOH}$ ) of non-thermally treated ores. On low temperature thermal treatment (at $250{ }^{\circ} \mathrm{C}-300^{\circ} \mathrm{C}$ ) with the addition of $\mathrm{NaOH}$ and leaching with water, and even without the addition of $\mathrm{NaOH}$ during thermal treatment but leaching with $\mathrm{NaOH}$ post-thermal treatment, they reported [258] better removal rates, i.e., about $60 \%$ at thermal treatment times $\geq 0.5 \mathrm{~h}$. They attributed the improvement after thermal treatment to the disruption and dehydration of the goethite structure and its conversion, through several intermediate phases, to hematite, which makes the associated phosphorus much more accessible to the leach solution, e.g., through the formation of protohematite, with higher porosity, and due to the structural disorder of the iron phase around $300{ }^{\circ} \mathrm{C}$.

The addition of $\mathrm{Na}_{2} \mathrm{CO}_{3}, \mathrm{CaCO}_{3}, \mathrm{CaO}$, and $\mathrm{Ca}(\mathrm{OH})_{2}$ to iron ores prior to thermal treatment have been shown [267-270] to be capable of suppressing the reduction of fluorapatite while promoting the reduction of iron oxides, and in some instances (e.g., at temperatures high enough for iron oxide reduction to iron), the growth of iron grains. This can enhance the feasibility of leaching pretreated ore with water (near-neutral $\mathrm{pH}$ leaching).

Yang et al. [37] studied roasting-induced phase changes and their influence on phosphorus removal by acid leaching of an iron ore with an average phosphorus content $0.85 \mathrm{wt} . \%$ (Huimin iron ore from Huimin County, Yunnan Province, China). They reported that while iron presented as hematite and goethite in the as-is ore with the non-detection of peaks for any phosphorus-containing minerals, upon roasting the iron ore at $300{ }^{\circ} \mathrm{C}$ for $1 \mathrm{~h}$ and below $500{ }^{\circ} \mathrm{C}$, goethite peaks were not observed in the XRD diffractograms. This phenomenon that was assumed to indicate that goethite transformed to hematite via a dehydration reaction. Upon heating to $600{ }^{\circ} \mathrm{C}-700{ }^{\circ} \mathrm{C}$, they reported [37] the emergence of peaks in XRD diffractogram for the phosphorus-containing mineral, grattarolaite $\left(\mathrm{Fe}_{3} \mathrm{PO}_{7}\right)$, and posited that phosphorus in the raw iron ore most likely exists in the amorphous form with goethite, but that its phase change to grattarolaite $\left(\mathrm{Fe}_{3} \mathrm{PO}_{7}\right)$ has little effect on the phosphorus removal rate from the ore, which was attributed to the low solubility of both the crystalline and the amorphous grattarolaite in the sulfuric acid used in their study. In contrast, upon heating the iron ore to temperatures $>800{ }^{\circ} \mathrm{C}$ (Figure 2), they [37] reported high phosphorus removal rates $(\geq 80 \%$ ). This was attributed to the reaction of grattarolaite $\left(\mathrm{Fe}_{3} \mathrm{PO}_{7}\right)$ with the alumina $\left(\mathrm{Al}_{2} \mathrm{O}_{3}\right)$ contained in the ore to form the more soluble aluminum phosphate $\left(\mathrm{AlPO}_{4}\right)$ at temperatures higher than $800{ }^{\circ} \mathrm{C}$ (Figure 3). This was evidenced by XRD diffractograms that showed the emergence of peaks for aluminum phosphate after roasting.

Rao et al. [271] employed additives $\left(\mathrm{Na}_{2} \mathrm{SO}_{4}\right.$ and $\left.\mathrm{Na}_{2} \mathrm{CO}_{3}\right)$ in a direct reduction process to enhance thermal reduction of phosphorus-rich oolitic hematite ore prior to recovery of dephosphorized iron by magnetic separation. They reported that the phosphorus content of the metallic iron phase in the pellets decreased markedly, with the mean phosphorus mass content in metallic iron grains decreasing from $0.877 \%$ to $0.02 \%$ as the sodium sulfate additive content varied from $0 \%$ to $20 \%$. Based on their analysis of the thermodynamics of the phase transformations of oolitic hematite ore during reduction, and the distribution of phosphorus in both metallic iron and the non-metallic phases, they [271] attributed phosphorus removal from the formed metallic iron, and its repartitioning to the gangue phase, to the presence of $\mathrm{SiO}_{2}$ and $\mathrm{Al}_{2} \mathrm{O}_{3}$, which, with addition of sodium sulfate, provided the thermodynamic driving force for the reduction of fluorapatite, generating $\mathrm{NaAlSiO}_{4}, \mathrm{CaAl}_{2} \mathrm{Si}_{2} \mathrm{O}_{8}$, and $\mathrm{CaNaPO}_{4}$. This report demonstrated that the thermal treatment of the iron ore with phosphorus presenting as fluoroapatite prior to thermal treatment resulted in the phosphorus presenting as a new phase, rhenanite $\left(\mathrm{CaNaPO}_{4}\right)$, which appears to selectively reside outside the metallic iron. Rhenanite $\left(\mathrm{CaNaPO}_{4}\right)$ is reported to possess a high solubility [272-274]. 


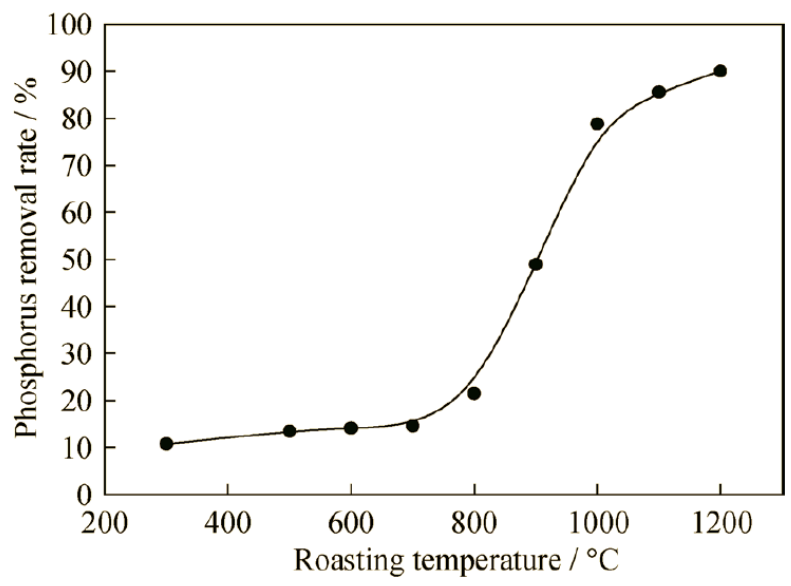

Figure 2. Effect of roasting temperature on phosphorus removal rate (roasting conditions: $1 \mathrm{~h}$; leaching conditions: $50{ }^{\circ} \mathrm{C}, 30 \mathrm{~min}, 0.13 \mathrm{~mol} / \mathrm{L} \mathrm{H}_{2} \mathrm{SO}_{4}$ ) (Reprinted by permission from Springer Nature and University of Science and Technology Beijing from Ref. [37]).

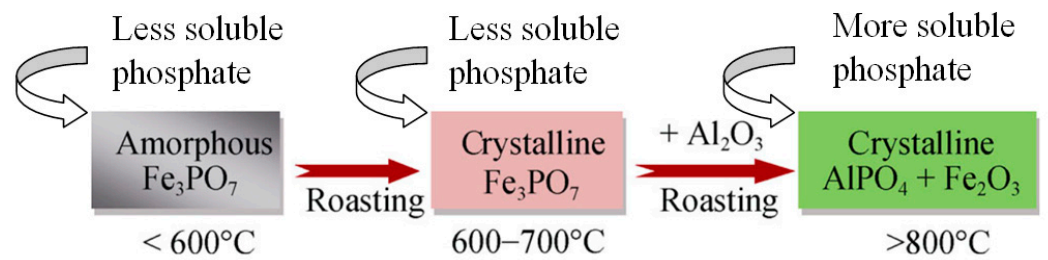

Figure 3. Phase transformation model of phosphorus in goethite (Adapted with permission from Springer Nature and University of Science and Technology Beijing from Ref. [37]).

Knabe et al. [275] reported a remarkably high solubility of $1.0 \mathrm{~g}$ per liter of $\mathrm{H}_{2} \mathrm{O}$ at $\mathrm{pH} 7$ for rhenanite $\left(\mathrm{CaNaPO}_{4}\right)$. This solubility is exploited in the "Rhenania process", which is the procedure used in the fertilizer industry to obtain soluble phosphate material [276]. The integration of this procedure into phosphorus removal strategies for iron ores can be quite beneficial, and more economical if the magnitude of the principal processing parameters, i.e., $1000{ }^{\circ} \mathrm{C}-1200^{\circ} \mathrm{C}$ for a few hours $[274,276]$, are reduced, as the resultant products are very likely to be amenable to leaching with water. Jalota et al. [274] demonstrated the synthesis of soluble rhenanite $\left(\mathrm{CaNaPO}_{4}\right)$ at temperatures below $700{ }^{\circ} \mathrm{C}$, i.e., less than the $900{ }^{\circ} \mathrm{C}-950{ }^{\circ} \mathrm{C}$ temperature range reported for the synthesis of phase-pure $\mathrm{CaNaPO}_{4}$ powders [277]. Though Rao et al. [271] did not consider post-thermal leaching in their work, a closer look at the solubility properties [275] of the new phase containing phosphorus, rhenanite $\left(\mathrm{CaNaPO}_{4}\right)$, leads the author to postulate that leaching (with acids, alkali, and/or water) might be a plausible strategy for phosphorus removal after pretreatments that transform the ore phosphorus contents to present as rhenanite

From this review of diverse recent research efforts, it is obvious that all these studies have generally involved a step aimed at changing the chemical and/or physical properties of the phosphorus-containing mineral/phase and/or that of the iron-rich mineral/phase to aid in the phosphorus removal from the ore. However, the question arises: are all the important relevant factors being taken into consideration in these studies?

\section{Important Insights and Relevant Factors from Recent Literature Reports}

By a survey of earlier and recent literature reports in a variety of areas, a range of salient and relevant factors which were hitherto unconsidered in the conceptualization and development of phosphorus removal strategies were identified.

Somasundaran et al. [278] conducted solubility, electrokinetic, spectroscopic, and flotation studies on apatite, calcite, monetite, magnesite, dolomite, gypsum, and anhydrite in aqueous systems, 
and observed complex mineral-solution interactions. From chemical equilibria and stability relations in heterogenous systems, and on the basis of bulk equilibrium in single, dual, and triple mineral systems in the presence and absence of carbon-dioxide, they were able to demonstrate the non-trivial role of atmospheric $\mathrm{CO}_{2}$ on the dissolution of apatite and calcite (both of which are important in phosphorus removal and recovery). The authors thus convincingly explained the wide and conflicting variations in the reported solubility behavior of apatites $[279,280]$ and phosphates $[142,279,280]$ on the basis of differences in the effective partial pressures of $\mathrm{CO}_{2}$ under different experimental conditions. By the application of Beck's theory on solubility [281], which postulates that the isoelectric point (IEP) of a solution in equilibrium with a solid phase will coincide with the $\mathrm{pH}$ of minimum solubility to their data, Somasundaran et al. [278] demonstrated that atmospheric carbon dioxide has an effect on the total solubility of apatite. In an earlier study [282], they reported on the effects of dissolved mineral species on the dissolution and precipitation behavior of apatite and calcite, which is also relevant to the development of phosphorus removal strategies. From these reports, it can be inferred that solution $\mathrm{pH}$, temperature, $\mathrm{CO}_{2}$ partial pressures, and the dissolved mineral species present in leach solutions are among the principal factors to be considered in the development of environmentally-benign and economic phosphorus removal/recovery strategies.

The solubility of calcium phosphates had been reported [283-285] to increase in the presence of solution carbonate. The increase is attributed to the formation of solution complexes such as $\mathrm{Ca}_{2} \mathrm{HPO}_{4} \mathrm{CO}_{3}$ and $\left(\mathrm{Ca}_{2} \mathrm{PO}_{4} \mathrm{CO}_{3}\right)$. Furthermore, a seven-fold increase was reported [286] in the solubility of hydroxyapatite in $1 \mathrm{mM} \mathrm{KCl}$ at $\mathrm{pH} 5$ on equilibration with $3.5 \mathrm{vol} . \% \mathrm{CO}_{2}$ in air. In light of these multiple reports on the influence of $\mathrm{CO}_{2}$, there is a need to study the effect of its presence in the leaching of high-phosphorus iron ores. This can be achieved either by leaching in the presence and exclusion of $\mathrm{CO}_{2}$, leaching in carbonic acid, and/or leaching in a desired leachant but with the addition of varying amounts of carbonic acid.

An analysis of a recent report by Stockdale et al. [96], in which an experimental simulation of atmospheric processes was employed to study the processes involved in atmospheric acid processing of phosphorus-bearing mineral dusts in order to determine the dissolution behavior of $\mathrm{P}$ compounds in dust and dust precursor soils, as well as their contributions in the supply of bioavailable phosphorus to the ocean, supports the plausibility of the aforementioned influence of $\mathrm{CO}_{2}$ on phosphorus dissolution and removal from high-phosphorus iron ores. They reported that acid dissolution occurred rapidly (in seconds to minutes) in a process controlled by the amount of $\mathrm{H}^{+}$ions present, and that at $\mathrm{H}^{+}<$ $10^{-4} \mathrm{~mol} / \mathrm{g}$ of dust, $1 \%-10 \%$ of the total $\mathrm{P}$ is dissolved, mainly due to dissolution of surface-bound forms ("desorption"). However, at higher $\mathrm{H}^{+}$concentrations $\left(\mathrm{H}^{+}>10^{-4} \mathrm{~mol} / \mathrm{g}\right.$ of dust), the amount of $\mathrm{P}$ and $\mathrm{Ca}$ released were directly proportional to the amount of $\mathrm{H}^{+}$consumed until all inorganic $\mathrm{P}$ minerals were exhausted, with the final $\mathrm{pH}$ remaining acidic. More important to the development of P-removal/recovery strategies is their report [96] that dissolved phosphorus remained in solution due to slow precipitation kinetics, and that the dissolution of apatite-P, the major mineral phase in dust (constituting 79\%-96\%), occurred whether calcium carbonate (calcite) was present or not, but that $\mathrm{P}$ dissolution was greater in the absence of calcite, which is in agreement with earlier reports $[278,283,284,286]$ on the possible influence of $\mathrm{CO}_{2}$ or carbonate on the dissolution behavior of phosphate minerals, and also reinforces the earlier call for study of the influence of the presence of $\mathrm{CO}_{2}$ on the leaching efficiency of high-P iron ores.

Photoreduction of iron compounds is another plausible important factor not yet taken into consideration in literature reports on phosphorus removal from high-phosphorus iron ores. The photoreduction of iron compounds (oxides and hydroxides) [287-291] and the consequent possibilities for its exploitation in catalytic applications [292-301] have been widely reported. Pehkonen et al. [287] studied the photoreduction of iron oxyhydroxides and natural iron-containing aerosol particles in the presence of important, atmospherically-relevant organic compounds (formaldehyde, formate, acetate, oxalate, and butyrate). They reported the photoproduction of $\mathrm{H}_{2} \mathrm{O}_{2}$, and that the important parameters in the photoreduction of iron compounds are $\mathrm{pH}$, the wavelength 
of the irradiating light, the nature of the electron donor, and the characteristics of the iron phase. Very importantly, they reported that the kinetics of photoreduction manifest a maximum at a wavelength of $330 \mathrm{~nm}$ with a continuous decrease to $405 \mathrm{~nm}$, which suggests that the photoreduction of iron compounds is most favored by exposure to radiation in the ultraviolet (UV-A: $315-400 \mathrm{~nm}$ ) range. However, Rijkenberg et al. [289], in their study on the effect of UV irradiation on the photoreduction of iron in the Southern Ocean, concluded that the UV part of the solar spectrum plays a major role in the photoreduction of iron, and that UVB (UV-B: $280-315 \mathrm{~nm}$ ) produced most of the Fe(II), followed by UVA (UV-A: $315-400 \mathrm{~nm}$ ) and visible light (VIS: 400-700 nm).

Photo-reductive dissolution of iron oxides (with $\mathrm{PO}_{4}$ sorbed onto their surfaces) is thought to lead to the release of adsorbed phosphorus into solution [302-304]. Cornell and Schindler [305] investigated the photochemical dissolution of goethite in acid/oxalate solution in a bid to determine the reaction products, the factors that govern the reaction rate, and to obtain a mechanistic understanding of the photochemical dissolution of iron oxides in natural systems. They reported that the reaction products were $\mathrm{Fe}^{3+}, \mathrm{Fe}^{2+}, \mathrm{CO}_{2}$, and ferrous oxalate, which is formed towards the end of the reaction by precipitation. This report of $\mathrm{CO}_{2}$ generation during photochemical dissolution of iron oxides in acid presents serious implications for the design of photochemical or photo-electrochemical systems for phosphorus removal; as the influence of $\mathrm{CO}_{2}$ on the dissolution behavior of phosphate minerals have been highlighted. Panias et al. [306], in their review on the mechanisms of the dissolution of iron oxides in aqueous oxalic acid solutions, stated that three distinct steps are involved: (a) the adsorption of organic ligands on the iron oxide surface; (b) nonreductive dissolution; and (c) reductive dissolution. They [306] also averred that reductive dissolution (which is consistent with the photo-dissolution of iron oxides) involved two stages: an induction period and an autocatalytic period, and that the time consuming induction step which can be reduced by the addition of bivalent iron $\left(\mathrm{Fe}^{2+}\right)$ into the initial solution and/or by UV irradiation of the solution. Phosphorus release from certain phosphorus compounds has been reported to occur under certain conditions [302,307-309]. The reduction of organically-complexed iron (III) by superoxide [310,311] opens the door to the plausible use of electrochemically- and locally-generated, short-lived reactive species in phosphorus removal/recovery from high-P iron ores. In addition, the photo-reduction of iron-bearing minerals (e.g., iron phosphates) can exert influences on the efficiency of the leaching process and iron loss during the leaching process under irradiation. Though the radiation wavelength region most likely to induce photoreduction is known, a good understanding of the effects of photo-reduction of iron-bearing minerals, the subsequent entry of iron into the leaching solution, and how its possible reprecipitation might affect the efficiency of leaching high-P iron ores, is not established and needs to be investigated.

Another plausible important factor that needs to be taken into consideration is the oxygen partial pressure, as this might exert an influence on iron entry and loss via the leach solution. Under oxic conditions (oxygen abundance) and the presence of iron ions in the leach solution, the presence of the more soluble ferric $\left(\mathrm{Fe}^{3+}\right)$ ion is likely to be favored, and hence, iron loss increased, as iron ions in solution act as a precipitant of phosphate ions in the leach solution [156]. In contrast, under anoxic (oxygen deficient) conditions, the presence of iron in solution in the less soluble ferrous $\left(\mathrm{Fe}^{2+}\right)$ is favored, which is likely to result in reduced iron loss into the leach solution, or as a precipitant of phosphate ions in solution. The application of these scenarios in phosphorus removal/recovery systems by control of oxygen partial pressure may be feasible over time durations of several minutes, as the half-time for oxygenation of ferrous ions $\left(\mathrm{Fe}^{2+}\right)$ has been reported to be about 16 minutes at $25^{\circ} \mathrm{C}$, $\mathrm{pH} \approx 7$, with a dissolved oxygen concentration of $2 \mathrm{mg} / 1[312,313]$.

Phosphorus removal and recovery from aqueous media is not a new technology; it has long been an integral part of waste water treatment and management. However, due to very significant differences in the operating $\mathrm{pH}$ and phosphorus loads in waste water compared to post-leach solutions, the phosphorus removal strategies currently employed in waste management are unsuitable for phosphorus recovery from phosphorus-rich leach solutions. In waste water treatment, the goal is often to reintroduce the water to natural water bodies after treatment. Hence, processing at near-neutral $\mathrm{pH}$ 
is desirable to mitigate the burden of the multiple $\mathrm{pH}$ adjustments that will be required if the process is being undertaken at the extremely low or high $\mathrm{pHs}$ that are characteristic of acid leaching and alkaline leaching respectively. Secondly, according to Machiela et al. [314], the phosphorus content in the alkaline leach solution from the leaching of oolitic iron ores with an initial P content of $0.8 \%$ and a solid-liquid ratio of $0.1 \mathrm{~g} / \mathrm{ml}$ can reach $600-700 \mathrm{mg} / \mathrm{L}$, while typical phosphorus loads in waste management are generally in the range of about $4-25 \mathrm{mg} / \mathrm{L}$ of total $\mathrm{P}$ for waste water $[315,316]$ and $40-300 \mathrm{mg} / \mathrm{L}$ total $\mathrm{P}$ for septic sludge ( $\mathrm{pH} 7-8.5)$ [316,317]. Machiela et al. [314], using a disodium phosphate solution containing $4785 \mathrm{mg}$ P and $5 \mathrm{wt} . \%(\approx 1.25 \mathrm{M})$ sodium hydroxide solution to simulate a phosphorus-loaded leaching solution with a $\mathrm{pH}$ of 14 , demonstrated the feasibility of $>99 \%$ phosphorus recovery with the simultaneous regeneration of an alkaline leach solution that had post-leaching phosphorus concentrations much higher than the typical values envisaged from the leaching of high-phosphorus iron ores using cheaper calcium hydroxide $\left(\mathrm{Ca}(\mathrm{OH})_{2}\right)$. In this procedure, the calcium cations $\left(\mathrm{Ca}^{2+}\right)$ from the added calcium hydroxide $\left(\mathrm{Ca}(\mathrm{OH})_{2}\right)$ act as a precipitant for the removal of phosphate anions from solution as insoluble calcium phosphates, while the concomitantly-added hydroxide anions $\left(\mathrm{OH}^{-}\right)$serve to maintain the high $\mathrm{pH}$ of the leach solution [314]. In contrast to the current use of "stoichiometric chemistry" in phosphorus/removal, which requires the addition of cheaper reagents, the development of catalytic and/or electrochemical methods involving the in-situ generation of the required reactive species would be quite beneficial.

\section{Plausible Strategies for Sustainable Phosphorus Removal from Different Iron Ores and Greener Ore Processing}

Effective phosphorus removal procedures from high-phosphorus iron ores are very likely to be ore-specific due to the significant variations in ore compositions, and to the presentation of phosphorus in the various high-phosphorus iron ores. Irrespective of ore composition, a general processing chart for phosphorus removal will have some common steps, including:

(a) If beneficial, a process step for physical separation of phosphorus from ore to reduce $\mathrm{P}$ content prior to further processing after ore communition to desirable particle size ranges, determined principally by the size of P-rich phases.

(b) A process step to thermally "remove" or reduce P content in ores and/or convert the phosphorus to forms that are more responsive to subsequent $P$ removal steps (usually leaching).

(c) A chemical processing step to reduce the $\mathrm{P}$ content of ores by its dissolution in processing media. For sustainable P-removal from high-phosphorus iron ores, the removed P needs to be recovered from P-rich processing media. Plausible routes to achieve this objective include:

(a) The introduction of free cations to support phosphorus precipitation as a phosphate.

(b) The electrochemical decomposition of soluble P-containing phases and/or stripping of $\mathrm{P}$ from processing media, preferably using energy from renewable sources.

(c) Recycling (reusing) of P-depleted leach solutions.

(d) The development of catalytic processes for P-removal and recovery to replace current stoichiometric processes.

The review of recent efforts at phosphorus removal from high-phosphorus iron ores (Section 7) indicates that these efforts have principally involved some form of thermal processing, or hydrometallurgical processing, or a combination of both. The most popular hydrometallurgical techniques employed are acid leaching, alkaline leaching, and bioleaching, each of which leaves a phosphorus-rich solution, often at a nonneutral $\mathrm{pH}$. Such a solution can be treated as waste, brought to near-neutral $\mathrm{pH}$ by the addition of an appropriate quantity of acid or base, and then disposed of at additional cost and with significant environmental implications, or as a "valorizable" intermediate product in a well-designed and integrated iron ore beneficiation and phosphorus recovery operation, with both economic and environmental benefits. Another possibility for the greener 
processing of high-phosphorus iron ores is the development of procedures that allow the stripping of phosphorus from the phosphorus-laden leachate and the reuse of the acidic or alkaline solution. Such a procedure will lead to a reduction in total acid or alkali consumption, with both economic and environmental benefits.

In this direction, Jin et al. [36] reported that the $\mathrm{pH}$ of their acidic leach solution (1\% sulfuric acid) after a leaching cycle was about 0.86 , inferring that this indicated that the acid was not exhausted, and hinting at the possibility of recycling the leaching solution. This report was corroborated by an earlier report by Asuke [44], who investigated phosphorus removal from Koton-karfe high-phosphorus iron ore (from Nigeria) by acid leaching using a variety of acids (sulfuric acid $\left(\mathrm{H}_{2} \mathrm{SO}_{4}\right)$, hydrochloric acid $(\mathrm{HCl})$, and citric acid $\left.\left(\mathrm{C}_{6} \mathrm{H}_{8} \mathrm{O}_{7}\right)\right)$, and reported insignificant changes in the $\mathrm{pH}$ of the respective leachant solutions after leaching, which raises the possibility of recycling the leaching solution. Sun et al. [318] recently reported interesting results on selective phosphorus recovery from high-phosphorus iron ore acid leach liquor using garlic peel as an adsorbent. Zhang and Muhammed [319] proposed an acid regenerating and integrated process for the treatment of apatite concentrate obtained from the acid dephosphorization of iron ore and solutions obtained from the direct leaching of iron ore for the simultaneous recovery of rare earths and phosphorus $\left(\right.$ as $\left.\mathrm{H}_{3} \mathrm{PO}_{4}\right)$. For iron ores with significant amounts of rare-earths [47,320-325], the incorporation of rare-earth recovery steps can improve the economy of the ore beneficiation process by yielding multiple streams of critical products (low-P iron ore, rare-earths, and phosphorus. Figure 4 presents a flow sheet of current efforts at the valorization of high-P iron ores, and highlights some plausible focal points for the development of a sustainable method.

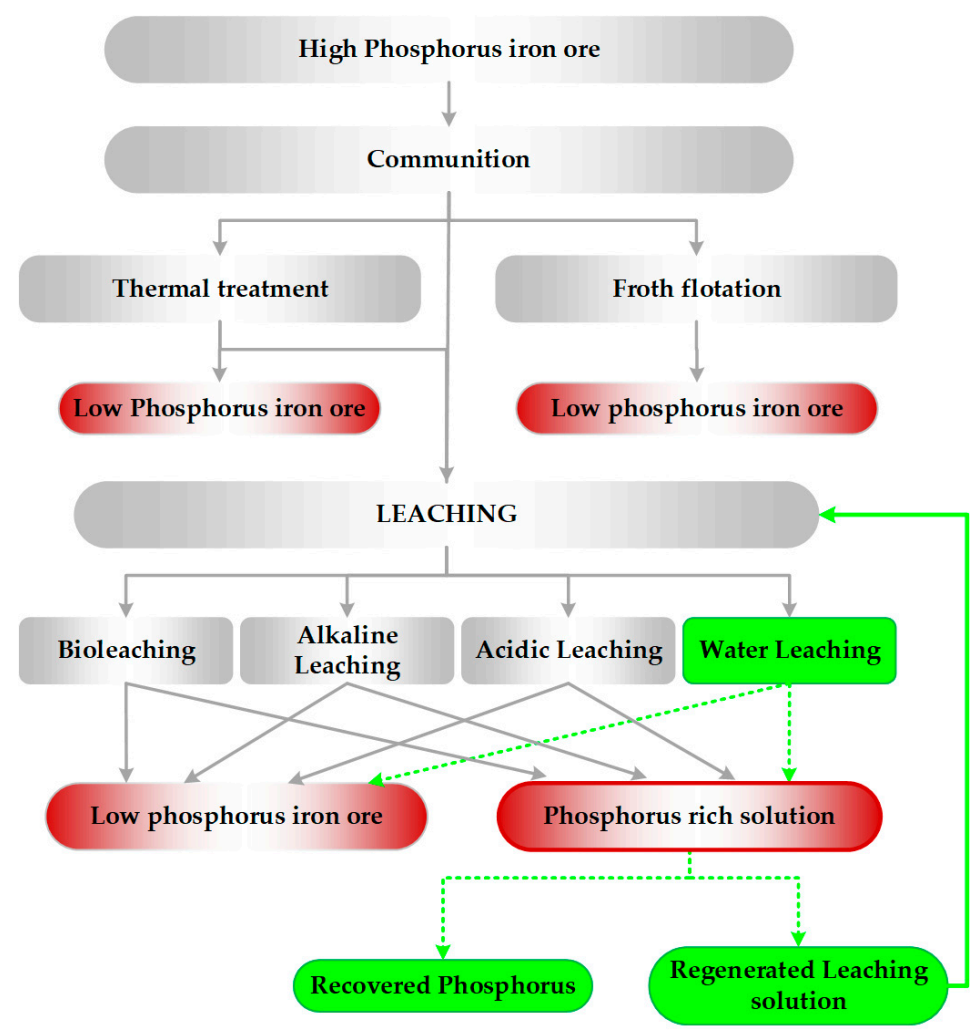

Figure 4. Plausible flow sheet for sustainable valorization of high-phosphorus ores (ecological steps are highlighted in green).

\section{Benefits of Phosphorus Recovery Versus Phosphorus Removal}

Mineral extraction and processing are seldom without significant environmental impacts. However, by the intelligent design of environmental risk-optimized processing routes which "valorize" a lot of 
the waste by making it amenable for use in other sectors or applications, its environmental impact can be significantly reduced. In this regard, an option for high-phosphorus ores could involve the design of new procedures that permit the phosphorus that was removed while beneficiating high-phosphorus iron ores to present in forms in which it is more bioavailable in soils to plants, and thus, to find use as a phosphorus-rich fertilizer. The development of such procedures will turn the phosphorus removal step into a phosphorus recovery step, thus reducing both the environmental impact and the economic cost of ore beneficiation through the potential income that would be generated from the recovered phosphorus.

Though phosphorus is unwanted in iron ores, both phosphorus and iron ore are important non-renewable resources. Consequently, the development of sustainable phosphorus recovery technology for high-P iron ores proffers solutions to two sustainability issues simultaneously. The demand for phosphorus in the agricultural sector as a fertilizer is enormous. Using data from 2009 and 2012, Tóth et al. [326] estimated the phosphorus input demand of croplands in the European Union to be about 3,849,873 tons of $\mathrm{P}_{2} \mathrm{O}_{5} /$ year, which is equivalent to $\approx 1.68 \times 10^{6}$ tons of P/year. Ueno and Fuji [327] communicated their experience in selling recovered phosphorus, and thus, demonstrated the feasibility of income generation from recovered phosphorus. In recognition of the fact that our global phosphorus reserve is finite and is projected to last between 60 to 240 years [328-331] based on current consumption habits and the marked inefficiency in the current phosphorus cycle [1],phosphorus recovery, recycling, reutilization, and management have become a subject of much interest [332-344], with established technologies for its recovery from a variety of waste sources, such as waste water [345-351], sewage [352-357], slag from metal processing [358,359], mining leachates [360,361], sewage sludge ash [362-365], manure [366-371], and human feces and urine [372-376]. Such an approach fits into the emerging and futuristic concept of green [377-383] and circular economies [384-389].

\section{Plausible Consequences of Ignoring the Challenge of Sustainable Valorization of High-P Iron Ores}

Though undesirable in steelmaking, phosphorus is a vital resource in the agricultural sector to ensure adequate food production and security. Phosphorus as phosphate rock is a finite resource, and the global distribution of phosphorus mineral reserves is extremely lopsided [344,390]. From data assembled by Villalba et al. [391] from different sources [392-394], it is evident that in the 16-year period from 1991-2007, only six countries (Brazil, China, Morocco, Russia, Tunisia, and the United States) consistently produced over three quarters $(\geq 77 \%)$ of global phosphorus output. This trend has significant geopolitical implications for phosphorus import-dependent nations and economic blocs like the EU [395,396]. For instance, Childers et al. [344] reported that China had briefly imposed a $135 \%$ tariff on phosphorus mineral exports in 2008-2009, in a move that effectively stopped phosphorus mineral exports during this period. Recent data [397,398] and its analysis [390] indicate that residual reserves of phosphate minerals are even more highly geographically-concentrated in a few countries, with Morocco and Western Sahara accounting for about $85 \%$ of remaining phosphate minerals reserves [390]. Hence, the development of technologies for the sustainable valorization of high-phosphorus iron ores through phosphorus removal and recovery can provide an alternative source for phosphorus, thus diluting the demand for phosphate rocks with significant global economic, environmental, and socio-political benefits. The geopolitical challenges of world trade in rare earths vis-a-vis protectionist and nationalistic policies of producing nations, and their implications for regional and global economies, are well documented [399-407]. If precautionary measures are not deployed to develop technologies that can supplement the dwindling high-grade iron ore reserves by the sustainable valorization of high-phosphorus iron ores, either phosphorus or iron ore, or both, might become the "rare-earths" of the future. The plausibility of this scenario and the volatility of iron ore prices to apparent supply constraints were recently demonstrated in surges in iron ore prices in China in response to a dam collapses in Brazil during the first quarter of 2019 that negatively impacted iron ore production and supplies from Brazil [408-410]. 


\section{Conclusions}

Dwindling reserves of natural resources and increasing environmental concerns call for a change in the way natural resources are extracted, processed, and used. Much of our recent and ongoing development is due to innovative methods of exploitation of an increasing range of materials; however, our sources of these materials, principally metals and the ores from which they are processed, are finite. Our demands for these materials are not abetting. Hence, resource depletion and scarcity are inevitable. Resource scarcity often leads to conflict and retarded growth. Issues of iron ore availability in the future might bear a lot of resemblance to current issues concerning the availability and trade of rare earths. To ensure resource and environmental sustainability, the processes currently employed in the extraction and processing of natural resources need to be modified. However, the resource-efficient, economic, and environmentally-benign processing of high-phosphorus iron ores to reduce their phosphorus content to levels which are acceptable for iron and steelmaking is a non-trivial technological and sustainability challenge. To stimulate interest in developing sustainable solutions to these challenges, phosphorus adsorption and association in iron oxides/hydroxyoxides and current efforts at its removal have been reviewed, key knowledge gaps that are vital for development of sustainable phosphorus removal/recovery strategies have been highlighted, and insights have been provided into plausible routes for the development of sustainable phosphorus recovery solutions from high-phosphorus iron ores. Emphasis was placed on strategies for the development of sustainable technologies with which to access iron in today's low-grade, high-phosphorus ores whilst simultaneously recovering the phosphorus for use in relevant industries with minimal environmental impact. The adoption of this approach is likely to mitigate at least two sustainability issues, i.e., continuous, less geographically-concentrated sources of both iron ore and phosphorus. It is envisaged that the issues, challenges, and plausible solutions highlighted in this review will stimulate the type of multidisciplinary crosstalk and collaboration needed to confront this potential sustainability challenge.

Funding: This work received no specific funding.

Conflicts of Interest: The author declares no conflict of interest.

\section{References}

1. Chen, M.; Graedel, T.E. A half-century of global phosphorus flows, stocks, production, consumption, recycling, and environmental impacts. Glob. Environ. Chang. 2016, 36, 139-152. [CrossRef]

2. Gargouri, K.; Mhiri, A. Relationship between soil fertility and phosphorus and potassium olive plant nutrition. In Proceedings of the 7th International Meeting on: Soils with Mediterranean Type of Climate, Valenzano, Italy, 23-28 September 2001.

3. Dodd, R.J.; Sharpley, A.N. Recognizing the role of soil organic phosphorus in soil fertility and water quality. Resour. Conserv. Recycl. 2015, 105, 282-293. [CrossRef]

4. Heckman, J.R. Soil Fertility Test Interpretation Phosphorus, Potassium, Magnesium, and Calcium. (Fact Sheet—FS719). Available online: https://ag.purdue.edu/agry/Purdue\%20Agroecology/Kteam/fs719. pdf?Mobile $=1 \&$ Source $=\% 2 \mathrm{Fa}$ (accessed on 10 September 2018).

5. Han, X.Z.; Tang, C.; Song, C.Y.; Wang, S.Y.; Qiao, Y.F. Phosphorus characteristics correlate with soil fertility of albic luvisols. Plant Soil 2005, 270, 47-56. [CrossRef]

6. Williams, C.H. Studies on soil phosphorus III. Phosphorus fractionation as a fertility index in South Australian soils. J. Agric. Sci. 1950, 40, 257-262. [CrossRef]

7. Garnache, C.; Swinton, S.M.; Herriges, J.A.; Lupi, F.; Stevenson, R.J. Solving the phosphorus pollution puzzle: Synthesis and directions for future research. Am. J. Agric. Econ. 2016, 98, 1334-1359. [CrossRef]

8. Fink, G.; Alcamo, J.; Flörke, M.; Reder, K. Phosphorus loadings to the world's largest lakes: Sources and trends. Glob. Biogeochem. Cycles 2018, 32, 617-634. [CrossRef]

9. David, M.H.; Joeres, E.F.; Peirce, J.J. Phosphorus pollution control in the Lake Michigan watershed. Policy Anal. 1980, 6, 47-60. 
10. Roy-Poirier, A.; Champagne, P.; Filion, Y. Bioretention processes for phosphorus pollution control. Environ. Rev. 2010, 18, 159-173. [CrossRef]

11. White, P.J.; Hammond, J.P. The sources of phosphorus in the waters of Great Britain. J. Environ. Qual. 2009, 38, 13-26. [CrossRef]

12. Lin, C.; Ma, R.; Xiong, J. Can the watershed non-point phosphorus pollution be interpreted by critical soil properties? A new insight of different soil P states. Sci. Total Environ. 2018, 628, 870-881. [CrossRef]

13. Correll, D.L. The role of phosphorus in the eutrophication of receiving waters: A review. J. Environ. Qual. 1998, 27, 261-266. [CrossRef]

14. Lee, G.F. Role of phosphorus in eutrophication and diffuse source control. In Phosphorus in Fresh Water and the Marine Environment; Elsevier: Amsterdam, The Netherlands, 2013; pp. 111-128. [CrossRef]

15. Carpenter, S.R. Phosphorus control is critical to mitigating eutrophication. Proc. Natl. Acad. Sci. USA 2008, 105, 11039-11040. [CrossRef] [PubMed]

16. Oliveira, M.; Machado, A.V. The role of phosphorus on eutrophication: A historical review and future perspectives. Environ. Technol. Rev. 2013, 2, 117-127. [CrossRef]

17. Chislock, M.F.; Doster, E.; Zitomer, R.A.; Wilson, A.E. Eutrophication: Causes, consequences, and controls in aquatic ecosystems. Nat. Educ. Knowl. 2013, 4, 10.

18. Schindler, D.W.; Carpenter, S.R.; Chapra, S.C.; Hecky, R.E.; Orihel, D.M. Reducing phosphorus to curb lake eutrophication is a success. Environ. Sci. Technol. 2016, 50, 8923-8929. [CrossRef]

19. Jarvie, H.P.; Sharpley, A.N.; Withers, P.J.; Scott, J.T.; Haggard, B.E.; Neal, C. Phosphorus mitigation to control river eutrophication: Murky waters, inconvenient truths, and "postnormal" science. J. Environ. Qual. 2013, 42, 295-304. [CrossRef]

20. Ofoegbu, S.U. Characterization studies on Agbaja iron ore: A high-phosphorus content ore. SN Appl. Sci. 2019, 1, 204. [CrossRef]

21. Xia, W.T.; Ren, Z.D.; Gao, Y.F. Removal of phosphorus from high phosphorus iron ores by selective $\mathrm{HCl}$ leaching method. J. Iron Steel Res. Int. 2011, 18, 1-4. [CrossRef]

22. Mudd, G.M. The Sustainability of Mining in Australia: Key Production Trends and Their Environmental Implications for the Future; Research Report No. RR5; Department of Civil Engineering, Monash University and Mineral Policy Institute: Victoria, Australia, April 2009.

23. Cheng, C.Y.; Misra, V.N.; Clough, J.; Muni, R. Dephosphorisation of western Australian iron ore by hydrometallurgical process. Miner. Eng. 1999, 12, 1083-1092. [CrossRef]

24. Graham, J. Phosphorus in Iron Ore from the Hamersley Iron Formations; Australasian Institute of Mining and Metallurgy: Carlton, Austrália, 1973; pp. 41-42.

25. Wells, M.A.; Ramanaidou, E.R. Occurrence and mineralogical association of phosphorus in Australian bedded iron ore deposits. In Proceedings of the Iron Ore Conference, Perth, Australia, 11-13 July 2011; pp. 331-336.

26. Nunes, A.P.L.; Pinto, C.L.L.; Valadão, G.E.S.; de Magalhães Viana, P.R. Floatability studies of wavellite and preliminary results on phosphorus removal from a Brazilian iron ore by froth flotation. Miner. Eng. 2012, 39, 206-212. [CrossRef]

27. Coelho, L.H.; Fonseca, L.; Kaneko, K.M.; Melo, J.C.A. A origem do fósforo e sua localização espacial nos minérios de ferro enriquecidos supergenicamente. In II Simp. Bras. Minério de Ferro; ABM: Ouro Preto, Brazil, 1999; pp. 44-52.

28. Nunes, A.P.L. Estudos Eletrocinéticos e de Flotabilidade de Wavellita, Turquesa, Senegalita e Apatita. Ph.D. Thesis, Universidade Federal de Minas Gerais, Minas Gerais, Brazil, July 2012.

29. Nunes, A.P.L.; Ribeiro, M.V.; Brandão, P.R.G.; Valadão, G.E.S. Caracterização de fosfatos secundários presentes em minério de ferro do quadrilátero ferrífero. In Proceedings of the 67 ABM Congress, Rio de Janeiro, Brazil, 31 July-3 August 2012.

30. Frost, R.L.; López, A.; Xi, Y.; Murta, N.; Scholz, R. The molecular structure of the phosphate mineral senegalite $\mathrm{Al}_{2}\left(\mathrm{PO}_{4}\right)(\mathrm{OH})_{3} \cdot 3 \mathrm{H}_{2} \mathrm{O}-\mathrm{A}$ vibrational spectroscopic study. J. Mol. Struct. 2013, 1048, 420-425. [CrossRef]

31. Nunes, A.P.L.; de Araujo, A.C.; de Magalhães, P.R.; Viana, A.B.H. Occurence of phosphorus-bearing minerals in Brazilian iron ores. In Proceedings of the GEOMIN 2009 Conference, First International Seminar on Geology for the Mining Industry, Antofagasta, Chile, 10-12 June 2009.

32. Sparks, B.; Sirianni, A. Beneficiation of a phosphoriferous iron ore by agglomeration methods. Int. J. Miner. Process. 2009, 1, 231-241. [CrossRef] 
33. Peng, T.; Gao, X.; Li, Q.; Xu, L.; Luo, L.; Xu, L. Phase transformation during roasting process and magnetic beneficiation of oolitic-iron ores. Vacuum 2017, 146, 63-73. [CrossRef]

34. Xiang, X.Y.; Xia, W.T.; Yuan, X.L.; Yin, J.G.; An, J. Removal of phosphorus from high phosphorus iron ores in Wushan mountain by crosscurrent acid leaching. Solid State Phenom. 2018, 279, 222-229. [CrossRef]

35. An, J.; Yang, W.Q.; Yuan, X.L.; Xia, W.T. Removal of phosphorus from high-phosphorus iron ores by sodium roasting. Adv. Mater. Res. 2014, 884-885, 228-232. [CrossRef]

36. Jin, Y.S.; Jiang, T.; Yang, Y.B.; Li, Q.; Li, G.H.; Guo, Y.F. Removal of phosphorus from iron ores by chemical leaching. J. Cent. South Univ. Technol. 2006, 13, 673-677. [CrossRef]

37. Yang, M.; Zhu, Q.S.; Fan, C.L.; Xie, Z.H.; Li, H.Z. Roasting-induced phase change and its influence on phosphorus removal through acid leaching for high-phosphorus iron ore. Int. J. Miner. Metall. Mater. 2015, 22, 346-352. [CrossRef]

38. Baioumy, H.; Omran, M.; Fabritius, T. Mineralogy, geochemistry and the origin of high-phosphorus oolitic iron ores of Aswan, Egypt. Ore Geol. Rev. 2017, 80, 185-199. [CrossRef]

39. Kolitsch, U.; Bernhardt, H.J.; Lengauer, C.L.; Blass, G.; Tillmanns, E. Allanpringite, $\mathrm{Fe}_{3}\left(\mathrm{PO}_{4}\right)_{2}(\mathrm{OH})_{3} \cdot 5 \mathrm{H}_{2} \mathrm{O}$, a new ferric iron phosphate from Germany, and its close relation to wavellite. Eur. J. Mineral. 2006, 18, 793-801. [CrossRef]

40. Tohry, A.; Dehghani, A. Effect of sodium silicate on the reverse anionic flotation of a siliceous-phosphorus iron ore. Sep. Purif. Technol. 2016, 164, 28-33. [CrossRef]

41. Ionkov, K.; Gaydardzhiev, S.; Bastin, D.; de Araujo, A.C.; Lacoste, M. Removal of phosphorous through roasting of oolitic iron ore with alkaline earth additives. In Proceedings of the XXVI International Mineral Processing Congress, New Delhi, India, 24-28 September 2012; pp. 2194-2205. Available online: http: //hdl.handle.net/2268/133978 (accessed on 15 January 2018).

42. Lovel, R.R.; Sparrow, G.J.; Fisher-White, M.J. Developments in chemical separation of iron ore. In Iron Ore: Mineralogy, Processing and Environmental Sustainability; Lu, L., Ed.; Elsevier: Amsterdam, The Netherlands, 2015; pp. 357-372.

43. Adedeji, F.A.; Sale, F.R. Characterization and reducibility of Itakpe and Agbaja (Nigerian) iron ores. Clay Miner. 1984, 19, 843-856. [CrossRef]

44. Asuke, F. A Study of the Dephosphorization of Koton-Karfe Iron Ore by Acidic Leaching. Ph.D. Thesis, Ahmadu Bello University, Zaria, Nigeria, May 2014. Available online: http://hdl.handle.net/123456789/5394 (accessed on 15 January 2018).

45. Gomes, M.E.P.; Ramos, J.M.F. Recursos Minerais de Trás-os-Montes e Alto Douro In Recursos Geológicos de Trás-os-Montes-Passado, Presente e Perspetivas Futuras; Balsa, C., Sobrinho Teixeira, J., Eds.; Instituto Politécnico de Bragança: Bragança, Portugal, 2018; p. 31. Available online: http://hdl.handle.net/10198/15491 (accessed on 18 November 2018).

46. EDSTRÖM, J.O. Optimized steelmaking from high phosphorus ores. Trans. Iron Steel Inst. Jpn. 1986, 26, 679-696. [CrossRef]

47. Parak, T. Phosphorus in different types of ore, sulfides in the iron deposits, and the type and origin of ores at Kiruna. Econ. Geol. 1985, 80, 646-665. [CrossRef]

48. Peixoto, G. Improvement of the Reduction Process in Phosphorus Content and Other Gangue in Iron Ore and Its Agglomerates. International Patent No. 93/10271, 1991.

49. Baker, M.J.; Blowes, D.W.; Ptacek, C.J. Laboratory development of permeable reactive mixtures for the removal of phosphorus from onsite wastewater disposal systems. Environ. Sci. Technol. 1998, 32, 2308-2316. [CrossRef]

50. Kim, J.; Li, W.; Philips, B.L.; Grey, C.P. Phosphate adsorption on the iron oxyhydroxides goethite $(\alpha-\mathrm{FeOOH})$, akaganeite $(\beta-\mathrm{FeOOH})$, and lepidocrocite $(\gamma-\mathrm{FeOOH})$ : A ${ }^{31} \mathrm{P}$ NMR Study. Energy Environ. Sci. 2011, 4, 4298-4305. [CrossRef]

51. Wang, L.; Putnis, C.; Hövelmann, J.; Putnis, A. Interfacial Precipitation of Phosphate on Hematite and Goethite. Minerals 2018, 8, 207. [CrossRef]

52. McBride, M.B. Trace and toxic elements in soils. Environmental chemistry of soils. In Environmental Chemistry of Soils; Oxford University Press: New York, NY, USA, 1994; pp. 308-341.

53. Memon, M.; Memon, K.S.; Akhtar, M.S.; Stüben, D. Characterization and quantification of iron oxides occurring in low concentration in soils. Commun. Soil Sci. Plant. Anal. 2009, 40, 162-178. [CrossRef] 
54. Morris, R.C. A Pilot Study of Phosphorus Distribution in Parts of the Brockman Iron Formation, Hamersley Group, Western Australia; Western Australia Department of Mines Annual Report; Geological Survey of Western Australia: Perth, Western Australia, 1973; pp. 75-81.

55. Barbour, A.P. Distribution of phosphorus in the iron ore deposits of Itabira, Minas Gerais, Brazil. Econ. Geol. 1973, 68, 52-64. [CrossRef]

56. Dukino, R.D. Phosphorus in Hamersley Range Iron Ore; BHP Internal Report; BHP Billiton: Melbourne, Australia, 1997.

57. Shannon, R.D. Revised effective ionic radii and systematic studies of interatomic distances in halides and chalcogenides. Acta Crystallogr. Sect. A 1976, 32, 751-767. [CrossRef]

58. Rothery, W.H. Researches on the nature, properties, and conditions of formation of intermetallic compounds, with special reference to certain compounds of tin-IV. J. Inst. Met. 1926, 35, 295-354.

59. Rothery, W.H. Researches on the Nature, Properties, and Conditions of Formation of Intermetallic Compounds, with Special Reference to Certain Compounds of Tin. Ph.D. Thesis, University of London, London, UK, 1926.

60. Rothery, W.H. Phase Stability in Metals and Alloys; Series in Material Science and Engineering; McGraw-Hill: New York, NY, USA, 1967; pp. 3-23.

61. Levard, C.; Borschneck, D.; Grauby, O.; Rose, J.; Ambrosi, J.P. Goethite, a tailor-made host for the critical metal scandium: The $\mathrm{Fe}_{\mathrm{x}} \mathrm{Sc}_{(1-\mathrm{x})} \mathrm{OOH}$ solid solution. Geochem. Perspect. Lett. 2018, 9, 16. [CrossRef]

62. Goldschmidt, V.M. Die Gesetze der Krystallochemie. Sci. Nat. 1926, 21, 477-485. [CrossRef]

63. Goldschmidt, V.; Videnskaps-Akad, S.; Oslo, I. Tolerance factor. Mat. Nat. 1926, Kl8, 5-116.

64. Choudhury, A.; Natarajan, S. A synthetic iron phosphate mineral, spheniscidite, $\left[\mathrm{NH}_{4}\right]^{+}\left[\mathrm{Fe}_{2}(\mathrm{OH})\left(\mathrm{H}_{2} \mathrm{O}\right)\left(\mathrm{PO}_{4}\right)_{2}\right]-\mathrm{H}_{2} \mathrm{O}$, exhibiting reversible dehydration. J. Chem. Sci. 1999, 111, 627-637. [CrossRef]

65. Pokrovski, G.S.; Schott, J.; Farges, F.; Hazemann, J.L. Iron (III)-silica interactions in aqueous solution: Insights from X-ray absorption fine structure spectroscopy. Geochim. Cosmochim. Acta 2003, 67, 3559-3573. [CrossRef]

66. Hoppe, U.; Kranold, R.; Stachel, D.; Barz, A.; Hannonb, A.C. Variation in PO bonding in phosphate glasses-a neutron diffraction study. Z. Naturforschung A 2000, 55, 369-380. [CrossRef]

67. Gagné, O.C.; Hawthorne, F.C. Bond-length distributions for ions bonded to oxygen: Results for the non-metals and discussion of lone-pair stereoactivity and the polymerization of PO. Acta Crystallogr. Sect. B Struct. Sci. Cryst. Eng. Mater. 2018, 74, 79-96. [CrossRef]

68. Bartell, L.S.; Su, L.S.; Yow, H. Lengths of phosphorus-oxygen and sulfur-oxygen bonds. Extended Hueckel molecular orbital examination of Cruickshank's d. pi.-p. pi. picture. Inorg. Chem. 1970, 9, 1903-1912. [CrossRef]

69. Gamoke, B.; Neff, D.; Simons, J. Nature of PO bonds in phosphates. J. Phys. Chem. A 2009, 113, 5677-5684. [CrossRef]

70. Gillis, R.G.; Horwood, J.F.; White, G.L. Bond refractions and the nature of phosphorus-oxygen bonds. J. Am. Chem. Soc. 1958, 80, 2999-3002. [CrossRef]

71. MacRae, C.M.; Wilson, N.C.; Pownceby, M.I.; Miller, P.R. The occurrence of phosphorus and other impurities in Australian iron ores. In Iron Ore 2011; The Australasian Institute of Mining and Metallurgy: Melbourne, Australia, 2011; pp. 281-289.

72. Fish, D.H.; Dietz, J.M. Use of Iron Oxides Produced from the Treatment of Coal Mine Drainage as Adsorbents to Remove Phosphorus from Secondary Wastewater Effluent; Final Report for OSM PA (AMD-04) Grant; Pennsylvania Department of Environmental Protection: Harrisburg, PA, USA, 2008.

73. Crosby, S.A.; Butler, E.I.; Turner, D.R.; Whltfield, M.; Glasson, D.R.; Millward, G.E. Phosphate adsorption onto iron oxyhydroxides at natural concentrations. Environ. Technol. 1981, 2, 371-378. [CrossRef]

74. Bastin, O.; Janssens, F.; Dufey, J.; Peeters, A. Phosphorus removal by a synthetic iron oxide-gypsum compound. Ecol. Eng. 1999, 12, 339-351. [CrossRef]

75. Huang, X.; Foster, G.D.; Honeychuck, R.V.; Schreifels, J.A. The maximum of phosphate adsorption at $\mathrm{pH}$ 4.0: Why it appears on aluminum oxides but not on iron oxides. Langmuir 2009, 25, 4450-4461. [CrossRef] [PubMed]

76. Sei, J.; Jumas, J.C.; Olivier-Fourcade, J.; Quiquampoix, H.; Staunton, S. Role of iron oxide on the phosphate adsorption properties of kaolinites from the Ivory Coast. Clays Clay Miner. 2002, 50, 217-222. [CrossRef]

77. Rietra, R.P.; Hiemstra, T.; van Riemsdijk, W.H. Interaction between calcium and phosphate adsorption on goethite. Environ. Sci. Technol. 2001, 35, 3369-3374. [CrossRef] [PubMed] 
78. Madrid, L.; De Arambarri, P. Adsorption of phosphate by two iron oxides in relation to their porosity. J. Soil Sci. 1985, 36, 523-530. [CrossRef]

79. Wang, X.; Liu, F.; Tan, W.; Li, W.; Feng, X.; Sparks, D.L. Characteristics of phosphate adsorption-desorption onto ferrihydrite: Comparison with well-crystalline Fe (hydr) oxides. Soil Sci. 2013, 178, 1-11. [CrossRef]

80. Villalobos, M.; Trotz, M.A.; Leckie, J.O. Variability in goethite surface site density: Evidence from proton and carbonate sorption. J. Colloid Interface Sci. 2003, 268, 273-287. [CrossRef]

81. Jonasson, R.G.; Martin, R.R.; Giuliacci, M.E.; Tazaki, K. Surface reactions of goethite with phosphate. J. Chem. Soc. Faraday Trans. 1988, 84, 2311-2315. [CrossRef]

82. Dideriksen, K.; Stipp, S.L.S. The adsorption of glyphosate and phosphate to goethite: A molecular-scale atomic force microscopy study. Geochim. Cosmochim. Acta 2003, 67, 3313-3327. [CrossRef]

83. Bolan, N.S.; Barrow, N.J.; Posner, A.M. Describing the effect of time on sorption of phosphate by iron and aluminium hydroxides. J. Soil Sci. 1985, 36, 187-197. [CrossRef]

84. Kwon, K.D.; Kubicki, J.D. Molecular orbital theory study on surface complex structures of phosphates to iron hydroxides: Calculation of vibrational frequencies and adsorption energies. Langmuir 2004, 20, 9249-9254. [CrossRef] [PubMed]

85. Lijklema, L. Interaction of orthophosphate with iron (III) and aluminum hydroxides. Environ. Sci. Technol. 1980, 14, 537-541. [CrossRef]

86. Abdala, D.B.; Northrup, P.A.; Arai, Y.; Sparks, D.L. Surface loading effects on orthophosphate surface complexation at the goethite/water interface as examined by extended X-ray Absorption Fine Structure (EXAFS) spectroscopy. J. Colloid Interface Sci. 2015, 437, 297-303. [CrossRef]

87. Helyar, K.R.; Munns, D.N.; Burau, R.G. Adsorption of phosphate by gibbsite: II. Formation of a surface complex involving divalent cations. J. Soil Sci. 1976, 27, 315-323. [CrossRef]

88. Hinkle, M.A.; Wang, Z.; Giammar, D.E.; Catalano, J.G. Interaction of Fe (II) with phosphate and sulfate on iron oxide surfaces. Geochim. Cosmochim. Acta 2015, 158, 130-146. [CrossRef]

89. Borch, T.; Fendorf, S. Phosphate interactions with iron (hydr) oxides: Mineralization pathways and phosphorus retention upon bioreduction. Dev. Earth Environ. Sci. 2007, 7, 321-348. [CrossRef]

90. Yin, J.; Lv, X.; Bai, C.; Qiu, G.; Ma, S.; Xie, B. Dephosphorization of iron ore bearing high phosphorous by carbothermic reduction assisted with microwave and magnetic separation. ISIJ Int. 2012, 52, 1579-1584. [CrossRef]

91. Mammadov, K. Dephosphorization of Iron Ore through Bioleaching. Master's Thesis, Instituto Politécnico de Bragança, Bragança, Portugal, June 2016. Available online: http://hdl.handle.net/10198/13176 (accessed on 10 February 2018).

92. Makris, K.C.; Harris, W.G.; O'Connor, G.A.; El-Shall, H. Long-term phosphorus effects on evolving physicochemical properties of iron and aluminum hydroxides. J. Colloid Interface Sci. 2005, 287, 552-560. [CrossRef]

93. Ruttenberg, K.C. Development of a sequential extraction method for different forms of phosphorus in marine sediments. Limnol. Oceanogr. 1992, 37, 1460-1482. [CrossRef]

94. Ruttenberg, K.C.; Ogawa, N.O.; Tamburini, F.; Briggs, R.A.; Colasacco, N.D.; Joyce, E. Improved, high-throughput approach for phosphorus speciation in natural sediments via the SEDEX sequential extraction method. Limnol. Oceanogr. Methods 2009, 7, 319-333. [CrossRef]

95. MacDonald, K.R. Evaluation of Selective Iron Extraction Techniques to Quantify Iron-Bound Phosphorus in Sediments. Master's Thesis, University of Hawaii, Honolulu, HI, USA, 2013.

96. Stockdale, A.; Krom, M.D.; Mortimer, R.J.; Benning, L.G.; Carslaw, K.S.; Herbert, R.J.; Shi, Z.; Myriokefalitakis, S.; Kanakidou, M.; Nenes, A. Understanding the nature of atmospheric acid processing of mineral dusts in supplying bioavailable phosphorus to the oceans. Proc. Natl. Acad. Sci. USA 2016, 113, 14639-14644. [CrossRef] [PubMed]

97. Gu, S.; Qian, Y.; Jiao, Y.; Li, Q.; Pinay, G.; Gruau, G. An innovative approach for sequential extraction of phosphorus in sediments: Ferrous iron P as an independent P fraction. Water Res. 2016, 103, 352-361. [CrossRef] [PubMed]

98. Wang, C.; Zhang, Y.; Li, H.; Morrison, R.J. Sequential extraction procedures for the determination of phosphorus forms in sediment. Limnology 2013, 14, 147-157. [CrossRef] 
99. Kraal, P.; Slomp, C.P.; Reed, D.C.; Reichart, G.J.; Poulton, S.W. Sedimentary phosphorus and iron cycling in and below the oxygen minimum zone of the northern Arabian Sea. Biogeosciences 2012, 9, $2603-2624$. [CrossRef]

100. Orihel, D.M.; Baulch, H.M.; Casson, N.J.; North, R.L.; Parsons, C.T.; Seckar, D.C.; Venkiteswaran, J.J. Internal phosphorus loading in Canadian fresh waters: A critical review and data analysis. Can. J. Fish. Aquat. Sci. 2017, 74, 2005-2029. [CrossRef]

101. Ni, J.; Lin, P.; Zhen, Y.; Yao, X.; Guo, L. Distribution, source and chemical speciation of phosphorus in surface sediments of the central Pacific Ocean. Deep Sea Res. Part I Oceanogr. Res. Pap. 2015, 105, 74-82. [CrossRef]

102. Al-Enezi, E.; Al-Shammari, F. Phosphorus speciation and trace metals in core sediment of Kuwait bay. In Petrogenesis and Exploration of the Earth's Interior; Doronzo, D., Schingaro, E., Armstrong-Altrin, J., Zoheir, B., Eds.; Advances in Science, Technology \& Innovation (IEREK Interdisciplinary Series for Sustainable Development); Springer: Cham, Switzerland, 2006. [CrossRef]

103. Defforey, D.; Paytan, A. Data report: Characteristics of sedimentary phosphorus at North Pond, IODP Expedition 336. Proc. IODP 2015, 336, 2-9. [CrossRef]

104. Nooney, M.G.; Murrell, T.S.; Corneille, J.S.; Rusert, E.I.; Hossner, L.R.; Goodman, D.W. A spectroscopic investigation of phosphate adsorption onto iron oxides. J. Vac. Sci. Technol. A Vac. Surf. Films 1996, 14, 1357-1361. [CrossRef]

105. Gooden, J.E.A.; Walker, W.M.; Allen, R.J. AMDEPHOS-A chemical process for dephosphorisation of iron ore. In Proceedings Second National Chemical Engineering Conference; The Institution of Chemical Engineers, University of Queensland: St. Lucia, Australia, 1974; pp. 38-48.

106. Belikov, V.V.; Ogorodov, V.B.; Jadryshnikov, A.O.; Mikhailovna, N.A.; Chop, S.V. Method for Cleaning of Iron Ore Concentrate from Phosphor Contaminants. RU Patent No. RU2184158, 2002.

107. Ionkov, K.; Gaydardzhiev, S.; Correa de Araujo, A.; Kokal, H.; Pirson, A.; Bastin, D. Dephosphorisation of limonitic concentrate by roasting, acid leaching and magnetic separation. In Iron Ore 2011; The Australasian Institute of Mining and Metallurgy: Melbourne, Australia, 2011; pp. 445-452. Available online: http: //hdl.handle.net/2268/97334 (accessed on 2 March 2018).

108. Sample, E.C.; Soper, R.J.; Racz, G.J. Reactions of phosphate fertilizers in soils. In The Role of Phosphorus in Agriculture; Khasawneh, F.E., Sample, E.C., Kamprath, E.J., Eds.; American Society of Agronomy: Madison, WI, USA, 1980; pp. 263-310.

109. Borggaard, O.K. The influence of iron oxides on phosphate adsorption by soil. J. Soil Sci. 1983, 34, $333-341$. [CrossRef]

110. Elbouaanani, L.K.; Malaman, B.; Gerardin, R. Structure refinement and magnetic properties of C-Fe( $\left(\mathrm{PO}_{3}\right)_{3}$ studied by neutron diffraction and Mössbauer techniques. J. Solid State Chem. 1999, 148, 455-463. [CrossRef]

111. Parada, C.; Perles, J.; Sáez-Puche, R.; Ruiz-Valero, C.; Snejko, N. Crystal growth, structure, and magnetic properties of a new polymorph of $\mathrm{Fe}_{2} \mathrm{P}_{2} \mathrm{O}_{7}$. Chem. Mater. 2003, 15, 3347-3351. [CrossRef]

112. Wentrup, H. Beitrag zum System Eisen-Phosphor-Sauerstoff. (Contribution on the system iron-phosphorus-oxygen). Archiv für das Eisenhüttenwesen 1935, 9, 57-60. (In German) [CrossRef]

113. Korinth, J.; Royen, P. Zur kenntnis der reduktion von metallsalzen. I. Reaktionen im System $\mathrm{Fe}_{2} \mathrm{O}_{3} / \mathrm{FePO}_{4}$. (Reaction in the system $\mathrm{Fe}_{2} \mathrm{O}_{3} / \mathrm{FePO}_{4}$ ). Zeitschrift für Anorganische und allgemeine Chemie 1961, 313, 121-137. (In German) [CrossRef]

114. Trömel, G.; Schwerdtfeger, K. Untersuchungen im system eisen-phosphor-sauerstoff. (A study of the system iron-phosphorous oxygen). Archiv für das Eisenhüttenwesen 1963, 34, 55-59. (In German) [CrossRef]

115. Modaressi, A.; Courtois, A.; Gerardin, R.; Malaman, B.; Gleitzer, C. $\mathrm{Fe}_{2} \mathrm{PO}_{5}$, un phosphate de fer de valence mixte. Préparation et études structurale, Mössbauer et magnétique. J. Solid State Chem. 1981, 40, 301-311. (In French) [CrossRef]

116. Modaressi, A.; Kaell, J.C.; Malaman, B.; Gerardin, R.; Gleitzer, C. Etude du system Fe-P-O (pour Fe/P $\geq 1$ ) et d'une famille: Les oxyphosphates de fer. ("Study of the system Fe-P-O (for Fe/P $\geq 1$ ) and its compounds: The Oxyphosphates of Iron"). Mater. Res. Bull. 1983, 18, 101-109. (In French) [CrossRef]

117. Kaell, J.C.; Jeannot, F.; Gleitzer, C. Étude de la reduction ménagée de $\mathrm{Fe}_{3}\left(\mathrm{PO}_{4}\right)_{2}$ et $\mathrm{Fe}_{9}\left(\mathrm{PO}_{4}\right) \mathrm{O}_{8}$. ("Study of the Progressive Reduction of $\mathrm{Fe}_{3}\left(\mathrm{PO}_{4}\right)_{2}$ and $\left.\mathrm{Fe}_{9}\left(\mathrm{PO}_{4}\right) \mathrm{O}_{8} . "\right)$. Ann. Chim. 1984, 9, 169-180. (In French)

118. Okada, S.; Yamamoto, T.; Okazaki, Y.; Yamaki, J.I.; Tokunaga, M.; Nishida, T. Cathode properties of amorphous and crystalline $\mathrm{FePO}_{4}$. J. Power Sources 2005, 146, 570-574. [CrossRef] 
119. Jin, M.; Chui, X.; Xu, W.; Liu, M. Mössbauer study of ferric phosphate catalysts. Hyperfine Interact. 1988, 41, 645-648. [CrossRef]

120. Rojo, J.M.; Mesa, J.L.; Lezama, L.; Rojo, T. Magnetic properties of the $\mathrm{Fe}\left(\mathrm{PO}_{3}\right)_{3}$ metaphosphate. J. Solid State Chem. 1999, 145, 629-633. [CrossRef]

121. Gleitzer, C. Anhydrous iron phosphates and oxyphosphates. Eur. J. Solid State Inorg. Chem. (Revue de Chimie Minerale) 1991, 22, 77-91. [CrossRef]

122. Bouchdoug, M.; Courtois, A.; Gerardin, R.; Steinmetz, J.; Gleitzer, C. Preparation et etude d'un oxyphosphate $\mathrm{Fe}_{4}\left(\mathrm{PO}_{4}\right)_{2} \mathrm{O}$. J. Solid State Chem. 1982, 42, 149-157. [CrossRef]

123. Hoggins, J.T.; Swinnea, J.S.; Steinfink, H. Crystal structure of $\mathrm{Fe}_{2} \mathrm{P}_{2} \mathrm{O}_{7}$. J. Solid State Chem. 1983, 47, $278-283$. [CrossRef]

124. Ijjaali, M.; Venturini, G.; Gerardin, R.; Malaman, B.; Gleitzer, C. Synthesis, Structure and Physical Properties of a Mixed-Valence Iron Diphosphate $\mathrm{Fe}_{3}\left(\mathrm{P}_{2} \mathrm{O}_{7}\right)_{2}$ : First Example of Trigonal Prismatic Fe2+ with O2-Ligands. Eur. J. Solid State Inorg. Chem. 1991, 22, 983-998. [CrossRef]

125. Malaman, B.; Ijjaali, M.; Gerardin, R.; Venturini, G.; Gleitzer, C. $\mathrm{Fe}_{7}\left(\mathrm{P}_{2} \mathrm{O}_{7}\right)_{4}$ a mixed-valence iron diphosphate, the missing link between $\mathrm{Fe}_{2} \mathrm{P}_{2} \mathrm{O}_{7}$ and $\mathrm{Fe}_{3}\left(\mathrm{P}_{2} \mathrm{O}_{7}\right)_{2}$. Eur. J. Solid State Inorg. Chem. 1993, 24, 1269-1284. [CrossRef]

126. Hong, Y.S.; Park, Y.J.; Ryu, K.S.; Chang, S.H. Crystalline $\mathrm{Fe}_{3} \mathrm{PO}_{7}$ as an electrode material for lithium secondary batteries. Solid State Ionics 2003, 156, 27-33. [CrossRef]

127. Moffat, J.B. Phosphates as catalysts. Catal. Rev. Sci. Eng. 1978, 18, 199-258. [CrossRef]

128. Forsyth, J.B.; Johnson, C.E.; Wilkinson, C. The magnetic structure of vivianite, $\mathrm{Fe}_{3}\left(\mathrm{PO}_{4}\right)_{2} .8 \mathrm{H}_{2} \mathrm{O}$. J. Phys. C Solid State Phys. 1970, 3, 1127. [CrossRef]

129. Padhi, A.K.; Nanjundaswamy, K.S.; Masquelier, C.; Okada, S.; Goodenough, J.B. Effect of structure on the $\mathrm{Fe}^{3+} / \mathrm{Fe}^{2+}$ redox couple in iron phosphates. J. Electrochem. Soc. 1997, 144, 1609-1613. [CrossRef]

130. Abrahams, S.C.; Bernstein, J.L. Crystal structure of paramagnetic ludlamite, $\mathrm{Fe}^{3}\left(\mathrm{PO}_{4}\right)_{2} \cdot 4 \mathrm{H}_{2} \mathrm{O}$, at $298^{\circ} \mathrm{K}$. J. Chem. Phys. 1966, 44, 2223-2229. [CrossRef]

131. Pan, H.B.; Darvell, B.W. Calcium phosphate solubility: The need for re-evaluation. Cryst. Growth Des. 2008, 9, 639-645. [CrossRef]

132. Valyashko, V.M.; Kogarko, L.N.; Khodakovskiy, I.L. Stability of fluorapatite, chlorapatite, and hydroxyapatite in aqueous solutions at different temperatures. Geochem. Int. 1968, 5, 21-30.

133. McCann, H.G. The solubility of fluorapatite and its relationship to that of calcium fluoride. Arch. Oral Biol. 1968, 13, 987-1001. [CrossRef]

134. Moreno, E.C.; Kresak, M.; Zahradnik, R.T. Physicochemical aspects of fluoride-apatite systems relevant to the study of dental caries. Caries Res. 1977, 11 (Suppl. 1), 142-171. [CrossRef] [PubMed]

135. Clark, J.S. Solubility criteria for the existence of hydroxyapatite. Can. J. Chem. 1955, 33, 1696-1700. [CrossRef]

136. Bell, L.C.; Mika, H.; Kruger, B.J. Synthetic hydroxyapatite-solubility product and stoichiometry of dissolution. Arch. Oral Biol. 1978, 23, 329-336. [CrossRef]

137. McDowell, H.; Gregory, T.M.; Brown, W.E. Solubility of $\mathrm{Ca}_{5}\left(\mathrm{PO}_{4}\right)_{3} \mathrm{OH}$ in the system $\mathrm{Ca}(\mathrm{OH})_{2}-\mathrm{H}_{3} \mathrm{PO}_{4}-\mathrm{H}_{2} \mathrm{O}$ at 5, 15, 25, and $37^{\circ}$ C. J. Res. Natl. Bur. Stand. Sect. A 1977, 81, 273-281. [CrossRef]

138. Patel, P.R.; Brown, W.E. Thermodynamic solubility product of human tooth enamel: Powdered sample. J. Dent. Res. 1975, 54, 728-736. [CrossRef]

139. McDowell, H.; Wallace, B.M.; Brown, W.E. The Solubilities of Hydroxyapatite at 5, 15, 25 and $37^{\circ} \mathrm{C}$; Abstracted, IADR Program and Abstracts of Papers, 47th General Meeting IADR, Abstract No. 340; IADR: Alexandria, VA, USA, 1969.

140. Avnimelech, Y.; Moreno, E.C.; Brown, W.E. Solubility and surface properties of finely divided hydroxyapatite. J. Res. Natl. Bur. Stand. Phys. Chem. A 1973, 77, 149-155. [CrossRef]

141. Chuong, R. Experimental study of surface and lattice effects on the solubility of hydroxyapatite. J. Dent. Res. 1973, 52, 911-914. [CrossRef]

142. Moreno, E.C.; Gregory, T.M.; Brown, W.E. Preparation and solubility of hydroxyapatite. J. Res. Natl. Bur. Stand. Phys. Chem. A 1968, 72A,773-782. [CrossRef]

143. Jaynes, W.F.; Moore, P.A.; Miller, D.M. Solubility and ion activity products of calcium phosphate minerals. J. Environ. Qual. 1999, 28, 530-536. [CrossRef] 
144. Gregory, T.M.; Moreno, E.C.; Patel, J.M.; Brown, W.E. Solubility of $\mathrm{Ca}_{3}\left(\mathrm{PO}_{4}\right)_{2}$ in the system $\mathrm{Ca}(\mathrm{OH})_{2}-\mathrm{H}_{3} \mathrm{PO}_{4}-\mathrm{H}_{2} \mathrm{O}$ at $5,15,25$, and $37^{\circ} \mathrm{C}$. J. Res. Natl. Bur. Stand. Phys. Chem. A 1974, 78A, 667-674. [CrossRef]

145. Moreno, E.C.; Brown, W.E.; Osborn, G. Stability of dicalcium phosphate dihydrate in aqueous solutions and solubility of octocalcium phosphate 1. Soil Sci. Soc. Am. J. 1960, 24, 99-102. [CrossRef]

146. McDowell, H. Solubility of $\mathrm{CaHPO}_{4}$ and Ion-Pair Formation. Ph.D. Thesis, Howard University, Washington DC, USA, 1968.

147. Sutter, J.R.; McDowell, H.; Brown, W.E. Solubility study of calcium hydrogen phosphate. Ion-Pair formation. Inorg. Chem. 1971, 10, 1638-1643. [CrossRef]

148. Patel, P.R.; Gregory, T.M.; Brown, W.E. Solubility of $\mathrm{CaHPO}_{4} \cdot 2 \mathrm{H}_{2} \mathrm{O}$ in the quaternary system $\mathrm{Ca}(\mathrm{OH})_{2}-\mathrm{H}_{3} \mathrm{PO}_{4}-\mathrm{NaCI}-\mathrm{H}_{2} \mathrm{O}$ at $25{ }^{\circ} \mathrm{C}$. J. Res. Nat. Bur. Stand. 1974, 78A, 675-681. [CrossRef]

149. Gregory, T.M.; Moreno, E.C.; Brown, W.E. Solubility of $\mathrm{CaHPO}_{4} \cdot 2 \mathrm{H}_{2} \mathrm{O}$ in the system $\mathrm{Ca}(\mathrm{OH}) 2-\mathrm{HPO} 4-$ $\mathrm{H} 2 \mathrm{O}$ at 5, 15, 25, $37.5^{\circ} \mathrm{C}$. J. Res. Natl. Bur. Stand. Phys. Chem. A 1970, 74A, 461-475. [CrossRef]

150. Moreno, E.C.; Brown, W.E.; Osborn, G. Solubility of dicalcium phosphate dihydrate in aqueous systems 1. Soil Sci. Soc. Am. J. 1960, 24, 94-98. [CrossRef]

151. Strates, B.S.; Neuman, W.F.; Levinskas, G.J. The solubility of bone mineral. II. Precipitation of Near-Neutral Solutions of Calcium.; Phosphate. J. Phys. Chem. 1957, 61, 279-282. [CrossRef]

152. Moreno, E.C.; Patel, J.M.; Gregory, T.M.; Brown, W.E. Solubility of whitlockite $/ \mathrm{\beta}-\mathrm{Ca}_{3}\left(\mathrm{PO}_{4}\right)_{2}$; Abstracted, IADR Program and Abstracts of Papers, No. 183; IADR: Alexandria, VA, USA, 1970.

153. Lide, D.R. (Ed.) CRC Handbook of Chemistry and Physics, 84th ed.; CRC Press: Bocan Raton, FL, USA, 2004.

154. Zharovskii, F.G. The solubility of phosphates. Trudy Kom. Anal. Khim. Akad. Nauk SSSR 1951, 3, 101-115. (In Russian)

155. Galal-Gorchev, H.; Stumm, W. The reaction of ferric iron with ortho-phosphate. J. Inorg. Nuclear Chem. 1963, 25, 567-574. [CrossRef]

156. Singer, P.C. Anaerobic control of phosphate by ferrous iron. J. Water Pollut. Control Fed. 1972, 44, $663-669$.

157. Nriagu, J.O. Solubility equilibrium constant of strengite. Am. J. Sci. 1972, 272, 476-484. [CrossRef]

158. Bache, B.W. Aluminium and iron phosphate studies relating to soils. J. Soil Sci. 1963, 14, 113-123. [CrossRef]

159. Chang, S.C.; Jackson, M.L. Solubility product of iron phosphate 1. Soil Sci. Soc. Am. J. 1957, 21, $265-269$. [CrossRef]

160. Al-Borno, A.; Tomson, M.B. The temperature dependence of the solubility product constant of vivianite. Geochim. Cosmochim. Acta 1994, 58, 5373-5378. [CrossRef]

161. Nriagu, J.O. Stability of vivianite and ion-pair formation in the system $\mathrm{Fe}_{3}\left(\mathrm{PO}_{4}\right)_{2}-\mathrm{H}_{3} \mathrm{PO}_{4}-\mathrm{H}_{2} \mathrm{O}$. Geochim. Cosmochim. Acta 1972, 36, 459-470. [CrossRef]

162. Rosenqvist, I.T. Formation of vivianite in Holocene clay sediments. Lithos 1970, 3, 327-334. [CrossRef]

163. Chen, P.J.; Faust, S.D. The solubility product of ferrous phosphate. Environ. Lett. 1974, 6, 287-296. [CrossRef]

164. Lindsay, W.L.; Peech, M.; Clark, J.S. Solubility criteria for the existence of variscite in soils 1. Soil Sci. Soc. Am. J. 1959, 23, 357-360. [CrossRef]

165. Veith, J.A.; Sposito, G. Reactions of aluminosilicates, aluminum hydrous oxides, and aluminum oxide with o-phosphate: The formation of x-ray amorphous analogs of variscite and montebrasite 1. Soil Sci. Soc. Am. J. 1977, 41, 870-876. [CrossRef]

166. Firsching, F.H.; Brune, S.N. Solubility products of the trivalent rare-earth phosphates. J. Chem. Eng. Data 1991, 36, 93-95. [CrossRef]

167. Magalhães, M.C.F.; Costa, M.O.G. On the solubility of whitlockite, $\mathrm{Ca} 9 \mathrm{Mg}\left(\mathrm{HPO}_{4}\right)\left(\mathrm{PO}_{4}\right)_{6}$, in aqueous solution at 298.15 K. Monatshefte für Chemie-Chem. Mon. 2018, 149, 253-260. [CrossRef]

168. Verbeeck, R.M.H.; De Bruyne, P.A.M.; Driessens, F.C.M.; Terpstra, R.A.; Verbeek, F. Solubility behaviour of Mg-containing $\beta-\mathrm{Ca}_{3}\left(\mathrm{PO}_{4}\right)_{2}$. Bulletin Des Sociétés Chimiques Belges 2010, 95, 455-476. [CrossRef]

169. Li, X.; Ito, A.; Sogo, Y.; Wang, X.; LeGeros, R.Z. Solubility of Mg-containing $\beta$-tricalcium phosphate at $25^{\circ} \mathrm{C}$. Acta Biomater. 2009, 5, 508-517. [CrossRef] [PubMed]

170. Poitrasson, F.; Oelkers, E.; Schott, J.; Montel, J.M. Experimental determination of synthetic $\mathrm{NdPO}_{4} \mathrm{monazite}^{\circ}$ end-member solubility in water from $21^{\circ} \mathrm{C}$ to $300{ }^{\circ} \mathrm{C}$ : Implications for rare earth element mobility in crustal fluids. Geochim. Cosmochim. Acta 2004, 68, 2207-2221. [CrossRef]

171. Tiessen, H. Phosphorus in the Global Environment: Transfers, Cycles, and Management; Wiley: Chichester, UK, 1995. 
172. Krumina, L.; Kenney, J.P.; Loring, J.S.; Persson, P. Desorption mechanisms of phosphate from ferrihydrite and goethite surfaces. Chem. Geol. 2016, 427, 54-64. [CrossRef]

173. Antelo, J.; Avena, M.; Fiol, S.; López, R.; Arce, F. Effects of pH and ionic strength on the adsorption of phosphate and arsenate at the goethite-water interface. J. Colloid Interface Sci. 2005, 285, 476-486. [CrossRef]

174. Luengo, C.; Brigante, M.; Antelo, J.; Avena, M. Kinetics of phosphate adsorption on goethite: Comparing batch adsorption and ATR-IR measurements. J. Colloid Interface Sci. 2006, 300, 511-518. [CrossRef]

175. Liu, F.; De Cristofaro, A.; Violante, A. Effect of $\mathrm{pH}$, phosphate and oxalate on the adsorption/desorption of arsenate on/from goethite. Soil Sci. 2001, 166, 197-208. [CrossRef]

176. Xu, N.; Christodoulatos, C.; Braida, W. Adsorption of molybdate and tetrathiomolybdate onto pyrite and goethite: Effect of $\mathrm{pH}$ and competitive anions. Chemosphere 2006, 62, 1726-1735. [CrossRef] [PubMed]

177. Elzinga, E.J.; Sparks, D.L. Phosphate adsorption onto hematite: An in-situ ATR-FTIR investigation of the effects of $\mathrm{pH}$ and loading level on the mode of phosphate surface complexation. J. Colloid Interface Sci. 2007, 308, 53-70. [CrossRef] [PubMed]

178. Ahmed, A.A.; Gypser, S.; Leinweber, P.; Freese, D.; Kühn, O. Infrared spectroscopic characterization of phosphate binding at the goethite-water interface. Phys. Chem. Chem. Phys. 2019, 21, 4421-4434. [CrossRef] [PubMed]

179. Torrent, J.; Barron, V.; Schwertmann, U. Phosphate adsorption and desorption by goethites differing in crystal morphology. Soil Sci. Soc. Am. J. 1990, 54, 1007-1012. [CrossRef]

180. Strauss, R.; Brümmer, G.W.; Barrow, N.J. Effects of crystallinity of goethite: I. Preparation and properties of goethites of differing crystallinity. Eur. J. Soil Sci. 1997, 48, 87-99. [CrossRef]

181. Strauss, R.; Brümmer, G.W.; Barrow, N.J. Effects of crystallinity of goethite: II. Rates of sorption and desorption of phosphate. European. J. Soil Sci. 1997, 48, 101-114. [CrossRef]

182. Colombo, C.; Barrón, V.; Torrent, J. Phosphate adsorption and desorption in relation to morphology and crystal properties of synthetic hematites. Geochim. Cosmochim. Acta 1994, 58, 1261-1269. [CrossRef]

183. Liu, F.; He, J.; Colombo, C.; Violante, A. Competitive adsorption of sulfate and oxalate on goethite in the absence or presence of phosphate. Soil Sci. 1999, 164, 180-189. [CrossRef]

184. Geelhoed, J.S.; Hiemstra, T.; Van Riemsdijk, W.H. Phosphate and sulfate adsorption on goethite: Single anion and competitive adsorption. Geochim. Cosmochim. Acta 1997, 61, 2389-2396. [CrossRef]

185. Manning, B.A.; Goldberg, S. Modeling competitive adsorption of arsenate with phosphate and molybdate on oxide minerals. Soil Sci. Soc. Am. J. 1996, 60, 121-131. [CrossRef]

186. Zhao, H.; Stanforth, R. Competitive adsorption of phosphate and arsenate on goethite. Environ. Sci. Technol. 2001, 35, 4753-4757. [CrossRef]

187. Chitrakar, R.; Tezuka, S.; Sonoda, A.; Sakane, K.; Ooi, K.; Hirotsu, T. Phosphate adsorption on synthetic goethite and akaganeite. J. Colloid Interface Sci. 2006, 298, 602-608. [CrossRef] [PubMed]

188. Goldberg, S. Chemical modeling of anion competition on goethite using the constant capacitance model 1. Soil Sci. Soc. Am. J. 1985, 49, 851-856. [CrossRef]

189. Hawke, D.; Carpenter, P.D.; Hunter, K.A. Competitive adsorption of phosphate on goethite in marine electrolytes. Environ. Sci. Technol. 1989, 23, 187-191. [CrossRef]

190. Gao, Y.; Mucci, A. Acid base reactions, phosphate and arsenate complexation, and their competitive adsorption at the surface of goethite in $0.7 \mathrm{M} \mathrm{NaCl}$ solution. Geochim. Cosmochim. Acta 2001, 65, 2361-2378. [CrossRef]

191. Violante, A.; Pigna, M.; Ricciardella, M.; Gianfreda, L. Adsorption of phosphate on variable charge minerals and soils as affected by organic and inorganic ligands. In Developments in Soil Science; Elsevier: Amsterdam, The Netherlands, 2002; Volume 28, pp. 279-295. [CrossRef]

192. Madrid, L.; Posner, A.M. Desorption of phosphate from goethite. J. Soil Sci. 1979, 30, 697-707. [CrossRef]

193. Kubicki, J.D.; Paul, K.W.; Kabalan, L.; Zhu, Q.; Mrozik, M.K.; Aryanpour, M.; Pierre-Louis, A.M.; Strongin, D.R. ATR-FTIR and density functional theory study of the structures, energetics, and vibrational spectra of phosphate adsorbed onto goethite. Langmuir 2012, 28, 14573-14587. [CrossRef]

194. Cabrera, F.; De Arambarri, P.; Madrid, L.; Toga, C.G. Desorption of phosphate from iron oxides in relation to equilibrium $\mathrm{pH}$ and porosity. Geoderma 1981, 26, 203-216. [CrossRef]

195. Martin, R.R.; Tazaki, K.; Smart, R.S.C. Direct observation of phosphate precipitation in the goethite/phosphate system. Soil Sci. Soc. Am. J. 1988, 52, 1492-1500. [CrossRef] 
196. Ler, A.; Stanforth, R. Evidence for surface precipitation of phosphate on goethite. Environ. Sci. Technol. 2003, 37, 2694-2700. [CrossRef]

197. Jia, Y.; Xu, L.; Fang, Z.; Demopoulos, G.P. Observation of surface precipitation of arsenate on ferrihydrite. Environ. Sci. Technol. 2006, 40, 3248-3253. [CrossRef] [PubMed]

198. Khare, N.; Hesterberg, D.; Martin, J.D. XANES investigation of phosphate sorption in single and binary systems of iron and aluminum oxide minerals. Environ. Sci. Technol. 2005, 39, 2152-2160. [CrossRef] [PubMed]

199. Wang, L.; Putnis, C.V.; Ruiz-Agudo, E.; Hövelmann, J.; Putnis, A. In situ imaging of interfacial precipitation of phosphate on goethite. Environ. Sci. Technol. 2015, 49, 4184-4192. [CrossRef] [PubMed]

200. Tejedor-Tejedor, M.I.; Anderson, M.A. The protonation of phosphate on the surface of goethite as studied by CIR-FTIR and electrophoretic mobility. Langmuir 1990, 6, 602-611. [CrossRef]

201. Persson, P.; Nilsson, N.; Sjöberg, S. Structure and bonding of orthophosphate ions at the iron oxide-aqueous interface. J. Colloid Interface Sci. 1996, 177, 263-275. [CrossRef] [PubMed]

202. Rahnemaie, R.; Hiemstra, T.; van Riemsdijk, W.H. Geometry, charge distribution, and surface speciation of phosphate on goethite. Langmuir 2007, 23, 3680-3689. [CrossRef]

203. Arroyave, J.M.; Puccia, V.; Zanini, G.P.; Avena, M.J. Surface speciation of phosphate on goethite as seen by InfraRed Surface Titrations (IRST). Spectrochim. Acta Part A Mol. Biomol. Spectrosc. 2018, 199, 57-64. [CrossRef]

204. Hingston, F.J.; Posner, A.M.; Quirk, J.P. Competitive adsorption of negatively charged ligands on oxide surfaces. Discuss. Faraday Soc. 1971, 52, 334-342. [CrossRef]

205. Waiman, C.V.; Arroyave, J.M.; Chen, H.; Tan, W.; Avena, M.J.; Zanini, G.P. The simultaneous presence of glyphosate and phosphate at the goethite surface as seen by XPS, ATR-FTIR and competitive adsorption isotherms. Colloids Surf. A Physicochem. Eng. Asp. 2016, 498, 121-127. [CrossRef]

206. Hiemstra, T.; Van Riemsdijk, W.H. A surface structural approach to ion adsorption: The charge distribution (CD) model. J. Colloid Interface Sci. 1996, 179, 488-508. [CrossRef]

207. Arai, Y.; Sparks, D.L. ATR-FTIR spectroscopic investigation on phosphate adsorption mechanisms at the ferrihydrite-water interface. J. Colloid Interface Sci. 2001, 241, 317-326. [CrossRef]

208. Nilsson, N.; Lövgren, L.; Sjöberg, S. Phosphate complexation at the surface of goethite. Chem. Speciat. Bioavailab. 1992, 4, 121-130. [CrossRef]

209. Zhong, B.; Stanforth, R.; Wu, S.; Chen, J.P. Proton interaction in phosphate adsorption onto goethite. J. Colloid Interface Sci. 2007, 308, 40-48. [CrossRef] [PubMed]

210. Antelo, J.; Fiol, S.; Pérez, C.; Mariño, S.; Arce, F.; Gondar, D.; López, R. Analysis of phosphate adsorption onto ferrihydrite using the CD-MUSIC model. J. Colloid Interface Sci. 2010, 347, 112-119. [CrossRef]

211. Gaboriaud, F.; Ehrhardt, J. Effects of different crystal faces on the surface charge of colloidal goethite(alpha-FeOOH) particles: An experimental and modeling study. Geochim. Cosmochim. Acta 2003, 67, 967-983. [CrossRef]

212. Cornell, R.M.; Schwertmann, U. The Iron Oxides: Structure, Properties, Reactions, Occurrences and Uses; Wiley-VCH: Weinheim, Germany, 1996.

213. Kosmulski, M.; Maczka, E.; Jartych, E.; Rosenholm, J.B. Synthesis and characterization of goethite and goethite-hematite composite: Experimental study and literature survey. Adv. Colloid Interface Sci. 2003, 103, 57-76. [CrossRef]

214. Appel, C.; Ma, L.Q.; Rhue, R.D.; Kennelley, E. Point of zero charge determination in soils and minerals via traditional methods and detection of electroacoustic mobility. Geoderma 2003, 113, 77-93. [CrossRef]

215. Cristiano, E.; Hu, Y.J.; Siegfried, M.; Kaplan, D.; Nitsche, H. A comparison of point of zero charge measurement methodology. Clays Clay Miner. 2011, 59, 107-115. [CrossRef]

216. Marsac, R.; Martin, S.; Boily, J.F.; Hanna, K. Oxolinic acid binding at goethite and akaganéite surfaces: Experimental study and modeling. Environ. Sci. Technol. 2015, 50, 660-668. [CrossRef]

217. Kozin, P.A. Charge Development at Iron Oxyhydroxide Surfaces: The Interplay between Surface Structure, Particle Morphology and Counterion Identity. Ph.D. Thesis, Umeå Universitet, Umeå, Sweden, 2014.

218. Sheydaei, M.; Aber, S. Preparation of nano-lepidocrocite and an investigation of its ability to remove a metal complex dye. CLEAN-Soil Air Water 2013, 41, 890-898. [CrossRef]

219. Kozin, P.A.; Salazar-Alvarez, G.; Boily, J.F. Oriented aggregation of lepidocrocite and impact on surface charge development. Langmuir 2014, 30, 9017-9021. [CrossRef] [PubMed] 
220. Borkovec, M.; Jönsson, B.; Koper, G.J. Ionization processes and proton binding in polyprotic systems: Small molecules, proteins, interfaces, and polyelectrolytes. In Surface and Colloid Science; Matijevic, E., Ed.; Springer: Boston, MA, USA, 2001; Volume 16, pp. 99-339.

221. Smith, G.W.; Salman, T. Zero-point-of-charge of hematite and zirconia. Can. Metall. Q. 1966, 5, 93-107. [CrossRef]

222. Vieira, A.P.; Berndt, G.; de Souza Junior, I.G.; Di Mauro, E.; Paesano, A.; de Santana, H.; da Costa, A.C.S.; Zaia, C.T.; Zaia, D.A. Adsorption of cysteine on hematite, magnetite and ferrihydrite: FT-IR, Mössbauer, EPR spectroscopy and X-ray diffractometry studies. Amino Acids 2011, 40, 205-214. [CrossRef] [PubMed]

223. Sverjensky, D.A. Zero-point-of-charge prediction from crystal chemistry and solvation theory. Geochim. Cosmochim. Acta 1994, 58, 3123-3129. [CrossRef]

224. Hu, J.; Chen, G.; Lo, I.M. Removal and recovery of Cr (VI) from wastewater by maghemite nanoparticles. Water Res. 2005, 39, 4528-4536. [CrossRef] [PubMed]

225. Nurdin, I. The effect of $\mathrm{pH}$ and time on the stability of superparamagnetic maghemite nanoparticle suspensions. In Proceedings of the 2015 2nd International Conference on Chemical and Material Engineering (ICCME 2015), Phuket, Thailand, 27-28 December 2015; MATEC Web of Conferences. EDP Sciences: Les Ulis, France, 2016; Volume 39, p. 01001. [CrossRef]

226. Schwertmann, U.; Fechter, H. The point of zero charge of natural and synthetic ferrihydrites and its relation to adsorbed silicate. Clay Miner. 1982, 17, 471-476. [CrossRef]

227. Sposito, G. The Chemistry of Soils; Oxford University Press: New York, NY, USA, 1989.

228. Zhou, Z.; Gunter, W.D. The nature of surface charge of kaolinite. Clays Clay Miner. 1992, 40, $365-368$. [CrossRef]

229. Parks, G.A. The isoelectric points of solid oxides, solid hydroxides, and aqueous hydroxo complex systems. Chem. Rev. 1965, 65, 177-198. [CrossRef]

230. Gulicovski, J.J.; Čerović, L.S.; Milonjić, S.K. Point of zero charge and isoelectric point of alumina. Mater. Manuf. Process. 2008, 23, 615-619. [CrossRef]

231. James, R.O.; Healy, T.W. Adsorption of hydrolyzable metal ions at the oxide-Water interface. I. Co (II) adsorption on $\mathrm{SiO} 2$ and $\mathrm{TiO} 2$ as model systems. J. Colloid Interface Sci. 1972, 40, 42-52. [CrossRef]

232. Riese, A.C. Adsorption of Radium and Thorium onto Quartz and Kaolinite: A Comparison of Solution/Surface Equilibria Models. Ph.D. Thesis, Colorado School of Mines, Golden, CO, USA, 1982.

233. Parks, G.A. Surface and interfacial free energies of quartz. J. Geophys. Res. Solid Earth 1984, 89, 3997-4008. [CrossRef]

234. Wei, S.; Tan, W.; Liu, F.; Zhao, W.; Weng, L. Surface properties and phosphate adsorption of binary systems containing goethite and kaolinite. Geoderma 2014, 213, 478-484. [CrossRef]

235. Shin, E.W.; Han, J.S.; Jang, M.; Min, S.H.; Park, J.K.; Rowell, R.M. Phosphate adsorption on aluminum-impregnated mesoporous silicates: Surface structure and behavior of adsorbents. Environ. Sci. Technol. 2004, 38, 912-917. [CrossRef] [PubMed]

236. Murashov, V.V.; Leszczynski, J. Adsorption of the phosphate groups on silica hydroxyls: An ab initio study. J. Phys. Chem. A 1999, 103, 1228-1238. [CrossRef]

237. Lee, Y.B.; Hoon, C.; Hwang, J.Y.; Lee, I.B.; Kim, P.J. Enhancement of phosphate desorption by silicate in soils with salt accumulation. Soil Sci. Plant. Nutr. 2004, 50, 493-499. [CrossRef]

238. Svatos, K.B. Commercial silicate phosphate sequestration and desorption leads to a gradual decline of aquatic systems. Environ. Sci. Pollut. Res. 2018, 25, 5386-5392. [CrossRef]

239. Kuwahara, Y.; Yamashita, H. Phosphate removal from aqueous solutions using calcium silicate hydrate prepared from blast furnace slag. ISIJ Int. 2017, 57, 1657-1664. [CrossRef]

240. Rājan, S.S.S.; Watkinson, J.H. Adsorption of selenite and phosphate on an allophane clay 1. Soil Sci. Soc. Am. J. 1976, 40, 51-54. [CrossRef]

241. Reitzel, K.; Andersen, F.Ø.; Egemose, S.; Jensen, H.S. Phosphate adsorption by lanthanum modified bentonite clay in fresh and brackish water. Water Res. 2013, 47, 2787-2796. [CrossRef]

242. Gérard, F. Clay minerals, iron/aluminum oxides, and their contribution to phosphate sorption in soils-A myth revisited. Geoderma 2016, 262, 213-226. [CrossRef]

243. Violante, A.; Pigna, M. Competitive sorption of arsenate and phosphate on different clay minerals and soils. Soil Sci. Soc. Am. J. 2002, 66, 1788-1796. [CrossRef] 
244. Van Oosterhout, F.; Lürling, M. The effect of phosphorus binding clay (Phoslock ${ }^{\circledR}$ ) in mitigating cyanobacterial nuisance: A laboratory study on the effects on water quality variables and plankton. Hydrobiologia 2013, 710, 265-277. [CrossRef]

245. Hertzog, E.S. A Study of the Occurrence and Amenability to Leaching of the Phosphorus Compounds in Some Red iron Ores; United States Bureau of Mines, Report of Investigations, RI 3294; United States Bureau of Mines: Washington, DC, USA, 1935; 9p.

246. Crawford, J. Solubility Data on 646 Common and Not So Common Minerals. Available online: https:// www.mindat.org/article.php/553/Solubility+Data+on+646+Common+and+Not+So+Common+Minerals (accessed on 5 February 2019).

247. Parfitt, R.L.; Atkinson, R.J.; Smart, R.S.C. The mechanism of phosphate fixation by iron oxides1. Soil Sci. Soc. Am. J. 1975, 39, 837. [CrossRef]

248. Goldberg, S.; Sposito, G. On the mechanism of specific phosphate adsorption by hydroxylated mineral surfaces: A review. Commun. Soil Sci. Plant. Anal. 1985, 16, 801-821. [CrossRef]

249. Liu, C.; Huang, P.M. Kinetics of phosphate adsorption on iron oxides formed under the influence of citrate. Can. J. Soil Sci. 2000, 80, 445-454. [CrossRef]

250. Li, M.; Liu, J.; Xu, Y.; Qian, G. Phosphate adsorption on metal oxides and metal hydroxides: A comparative review. Environ. Rev. 2016, 24, 319-332. [CrossRef]

251. Fang, H.; Cui, Z.; He, G.; Huang, L.; Chen, M. Phosphorus adsorption onto clay minerals and iron oxide with consideration of heterogeneous particle morphology. Sci. Total Environ. 2017, 605, 357-367. [CrossRef]

252. Torrent, J.; Schwertmann, U.; Barron, V. Fast and slow phosphate sorption by goethite-rich natural materials. Clays Clay Miner. 1992, 40, 14-21. [CrossRef]

253. Borggaard, O.K. Effect of surface area and mineralogy of iron oxides on their surface charge and anion-adsorption properties. Clays Clay Miner. 1983, 31, 230-232. [CrossRef]

254. Guzman, G.; Alcantara, E.; Barron, V.; Torrent, J. Phytoavailability of phosphate adsorbed on ferrihydrite, hematite, and goethite. Plant. Soil 1994, 159, 219-225. [CrossRef]

255. Colombo, C.; Buondonno, A.; Violante, A.; Torrent, J. The contrasting effect of goethite and hematite on phosphate sorption and desorption by Terre Rosse. Zeitschrift für Pflanzenernährung und Bodenkunde 1991, 154, 301-305. [CrossRef]

256. Ruan, H.D.; Gilkes, R.J. Kinetics of phosphate sorption and desorption by synthetic aluminous goethite before and after thermal transformation to hematite. Clay Miner. 1996, 31, 63-74. [CrossRef]

257. Tang, H.Q.; Guo, Z.C.; Zhao, Z.L. Phosphorus removal of high phosphorus iron ore by gas-based reduction and melt separation. J. Iron Steel Res. Int. 2010, 17, 1-6. [CrossRef]

258. Fisher-White, M.J.; Lovel, R.R.; Sparrow, G.J. Phosphorus removal from goethitic iron ore with a low temperature heat treatment and a caustic leach. ISIJ Int. 2012, 52, 797-803. [CrossRef]

259. D'Orey, F.L.C. The detrital origin of the Moncorvo ordovician ironstones. Ciências Da Terra/Earth Sci. J. 2009, 13, 131-140.

260. Urbano, E.E.M.C. Génese do Jazigo de ferro de Moncorvo e Avaliação do uso de Equipamentos Portáteis de FRX e DRX Para a Exploração Mineral Deste tipo de Jazigos. Ph.D. Thesis, Universidade de Trás-os-Montes e Alto Douro, Vila Real, Portugal, 2017.

261. Neiva, J.M. Geologia dos Minérios de Ferro Portugueses: Seu Interesse Para a Siderurgia. Museu Mineralógico e Geológico. 1949. Available online: http://hdl.handle.net/10316.2/37963 (accessed on 10 May 2019).

262. Rath, S.S.; Dhawan, N.; Rao, D.S.; Das, B.; Mishra, B.K. Beneficiation studies of a difficult to treat iron ore using conventional and microwave roasting. Powder Technol. 2016, 301, 1016-1024. [CrossRef]

263. Omran, M.; Fabritius, T.; Elmahdy, A.M.; Abdel-Khalek, N.A.; El-Aref, M.; Elmanawi, A.E.H. XPS and FTIR spectroscopic study on microwave treated high phosphorus iron ore. Appl. Surf. Sci. 2015, 345, 127-140. [CrossRef]

264. Omran, M.; Fabritius, T.; Mattila, R. Thermally assisted liberation of high phosphorus oolitic iron ore: A comparison between microwave and conventional furnaces. Powder Technol. 2015, 269, 7-14. [CrossRef]

265. Omran, M.; Fabritius, T.; Elmahdy, A.M.; Abdel-Khalek, N.A.; Gornostayev, S. Improvement of phosphorus removal from iron ore using combined microwave pretreatment and ultrasonic treatment. Sep. Purif. Technol. 2015, 156, 724-737. [CrossRef]

266. Peng, Z.; Hwang, J.Y. Microwave-assisted metallurgy. Int. Mater. Rev. 2015, 60, 30-63. [CrossRef] 
267. Bai, S.; Wen, S.; Liu, D.; Zhang, W.; Cao, Q. Beneficiation of high phosphorus limonite ore by sodium-carbonate-added carbothermic reduction. ISIJ Int. 2012, 52, 1757-1763. [CrossRef]

268. Yu, W.; Sun, T.; Kou, J.; Wei, Y.; Xu, C.; Liu, Z. The function of $\mathrm{Ca}(\mathrm{OH})_{2}$ and $\mathrm{Na}_{2} \mathrm{CO}_{3}$ as additive on the reduction of high-phosphorus oolitic hematite-coal mixed pellets. ISIJ Int. 2013, 53, 427-433. [CrossRef]

269. Han, H.; Duan, D.; Wang, X.; Chen, S. Innovative method for separating phosphorus and iron from high-phosphorus oolitic hematite by iron nugget process. Metall. Mater. Trans. B 2014, 45, 1634-1643. [CrossRef]

270. Li, Y.L.; Sun, T.C.; Xu, C.Y.; Liu, Z.H. New dephosphorizing agent for phosphorus removal from high-phosphorus oolitic hematite ore in direct reduction roasting. J. Cent. South Univ. (Sci. Technol.) 2012, 3, 827-834.

271. Rao, M.; Ouyang, C.; Li, G.; Zhang, S.; Zhang, Y.; Jiang, T. Behavior of phosphorus during the carbothermic reduction of phosphorus-rich oolitic hematite ore in the presence of $\mathrm{Na}_{2} \mathrm{SO}_{4}$. Int. J. Miner. Process. 2015, 143, 72-79. [CrossRef]

272. Tang, R.; Hass, M.; Wu, W.; Gulde, S.; Nancollas, G.H. Constant composition dissolution of mixed phases: II. Selective dissolution of calcium phosphates. J. Colloid Interface Sci. 2003, 260, 379-384. [CrossRef]

273. Kwon, S.H.; Jun, Y.K.; Hong, S.H.; Kim, H.E. Synthesis and dissolution behavior of $\beta$-TCP and HA/ $\beta$-TCP composite powders. J. Eur. Ceram. Soc. 2003, 23, 1039-1045. [CrossRef]

274. Jalota, S.; Bhaduri, S.B.; Tas, A.C. A new rhenanite $\left(\beta-\mathrm{NaCaPO}_{4}\right)$ and hydroxyapatite biphasic biomaterial for skeletal repair. J. Biomed. Mater. Res. Part B 2007, 80, 304-316. [CrossRef]

275. Knabe, C.; Berger, G.; Gildenhaar, R.; Howlett, C.R.; Markovic, B.; Zreiqat, H. The functional expression of human bone-derived cells grown on rapidly resorbable calcium phosphate ceramics. Biomaterials 2004, 25, 335-344. [CrossRef]

276. Glasser, F.P.; Gunawardane, R.P. Fertilizer Material from Apatite. U.S. Patent 4,436,546, 13 March 1984.

277. Ben Amara, M.; Vlasse, M.; Le Flem, G.; Hagenmuller, P. Structure of the low-temperature variety of calcium sodium orthophosphate, $\mathrm{NaCaPO}_{4}$. Acta Crystallogr. Sect. C Cryst. Struct. Commun. 1983, 39, 1483-1485. [CrossRef]

278. Somasundaran, P.; Amankonah, J.O.; Ananthapadmabhan, K.P. Mineral—solution equilibria in sparingly soluble mineral systems. Colloids Surf. 1985, 15, 309-333. [CrossRef]

279. Brown, W.E. Solubility of Phosphates and Other Sparingly Soluble Compounds. In Environmental Phosphorus Handbook; Griffith, E.J., Alfred, B., Spencer, J.M., Mitchell, D.T., Eds.; Wiley: New York, NY, USA, 1973; pp. 203-239.

280. Brown, W.E. Physicochemistry of Apatite Dissolution (Physicochimie et Cristallographie des Apatites d'IntEet Biologique); Centre National de la Recherche Scientifique: Paris, France, 1975; pp. 355-368.

281. Beck, M.T. Correlation between the isoelectric point and stability of complex compounds. Acta Chim. Acad. Sci. Hung. 1954, 4, 227.

282. Amankonah, J.O.; Somasundaran, P.; Ananthapadmanabhan, K.P. Effect of Dissolved Mineral Species on the Dissolution/Precipitation Characteristics of Calcite and Apatite. Colloids Surf. 1985, 15, 295-307. [CrossRef]

283. Greenwald, I. The effect of phosphate on the solubility of calcium carbonate and of bicarbonate on the solubility of calcium and magnesium phosphates. J. Biol. Chem. 1945, 161, 697-704.

284. Grøn, P.; Spinelli, M.; Trautz, O.; Brudevold, F. The effect of carbonate on the solubility of hydroxylapatite. Arch. Oral Biol. 1963, 8, 251-263. [CrossRef]

285. Pan, H.; Darvell, B.W. Effect of carbonate on hydroxyapatite solubility. Cryst. Growth Des. 2010, 10, 845-850. [CrossRef]

286. Chen, Z.F.; Darvell, B.W.; Leung, V.H. Hydroxyapatite solubility in simple inorganic solutions. Arch. Oral Biol. 2004, 49, 359-367. [CrossRef]

287. Pehkonen, S.O.; Siefert, R.; Erel, Y.; Webb, S.; Hoffmann, M.R. Photoreduction of iron oxyhydroxides in the presence of important atmospheric organic compounds. Environ. Sci. Technol. 1993, 27, 2056-2062. [CrossRef]

288. Pehkonen, S.O.; Siefert, R.L.; Hoffmann, M.R. Photoreduction of iron oxyhydroxides and the photooxidation of halogenated acetic acids. Environ. Sci. Technol. 1995, 29, 1215-1222. [CrossRef]

289. Rijkenberg, M.J.A.; Fischer, A.C.; Kroon, J.J.; Gerringa, L.J.A.; Timmermans, K.R.; Wolterbeek, H.T.; De Baar, H.J.W. The influence of UV irradiation on the photoreduction of iron in the Southern Ocean. Mar. Chem. 2005, 93, 119-129. [CrossRef] 
290. Waite, T.D.; Morel, F.M. Photoreductive dissolution of colloidal iron oxides in natural waters. Environ. Sci. Technol. 1984, 18, 860-868. [CrossRef]

291. Krizek, D.T.; Bennett, J.H.; Brown, J.C.; Zaharieva, T.; Norris, K.H. Photochemical reduction of iron. I. Light reactions. J. Plant Nutr. 1982, 5, 323-333. [CrossRef]

292. Feng, W.; Nansheng, D. Photochemistry of hydrolytic iron (III) species and photoinduced degradation of organic compounds. A minireview. Chemosphere 2000, 41, 1137-1147. [CrossRef]

293. Wu, F.; Deng, N.; Zuo, Y. Discoloration of dye solutions induced by solar photolysis of ferrioxalate in aqueous solutions. Chemosphere 1999, 39, 2079-2085. [CrossRef]

294. Goldberg, M.C.; Cunningham, K.M.; Weiner, E.R. Aquatic photolysis: Photolytic redox reactions between goethite and adsorbed organic acids in aqueous solutions. J. Photochem. Photobiol. A Chem. 1993, 73, 105-120. [CrossRef]

295. Deng, N.; Fang, T.; Tian, S. Photodegradation of dyes in aqueous solutions containing Fe (II)-hydroxy complex I. Photodegradation kinetics. Chemosphere 1996, 33, 547-557. [CrossRef]

296. Zhang, Z.; Wu, F.; Deng, N. Photochemical reduction of Cr (VI) in aqueous solutions containing Fe (III)-hydroxy complexes. Toxicol. Environ. Chem. 2002, 82, 129-137. [CrossRef]

297. Xu, J.; Li, J.; Wu, F.; Zhang, Y. Rapid photooxidation of As (III) through surface complexation with nascent colloidal ferric hydroxide. Environ. Sci. Technol. 2013, 48, 272-278. [CrossRef]

298. Luo, F.; Deng, N.; Wu, F.; Zuo, Y. UV-light induced discoloration of dye solutions in the presence of Fe (iii) and humic acid. Toxicol. Environ. Chem. 1999, 71, 125-134. [CrossRef]

299. Grodkowski, J.; Neta, P. Ferrous ions as catalysts for photochemical reduction of $\mathrm{CO}_{2}$ in homogeneous solutions. J. Phys. Chem. A 2000, 104, 4475-4479. [CrossRef]

300. Nishihama, S.; Hirai, T.; Komasawa, I. High Functional Liquid-Liquid Extraction System Using Photochemical Reduction for Metal Ions. In Solvent Extraction Research and Development, Japan; Japan Association of Solvent Extraction: Osaka, Japan, 2001; Volume 8, p. 172.

301. Kumar, B.; Llorente, M.; Froehlich, J.; Dang, T.; Sathrum, A.; Kubiak, C.P. Photochemical and photoelectrochemical reduction of $\mathrm{CO}_{2}$. Annu. Rev. Phys. Chem. 2012, 63, 541-569. [CrossRef]

302. Francko, D.A.; Heath, R.T. UV-sensitive complex phosphorus: Association with dissolved humic material and iron in a bog lake 1. Limnol. Oceanogr. 1982, 27, 564-569. [CrossRef]

303. McKnight, D.M. Metal-Tolerant Algae in St. Kevin Gulch; Mallard, G.E., Ed.; U.S. Geological Survey: Pueblo, CO, USA, 1988; pp. 113-117.

304. Tate, C.M.; Broshears, R.E.; McKnight, D.M. Phosphate dynamics in an acidic mountain stream: Interactions involving algal uptake, sorption by iron oxide, and photoreduction. Limnol. Oceanogr. 1995, 40, 938-946. [CrossRef]

305. Cornell, R.M.; Schindler, P.W. Photochemical dissolution of goethite in acid/oxalate solution. Clays Clay Miner. 1987, 35, 347-352. [CrossRef]

306. Panias, D.; Taxiarchou, M.; Paspaliaris, I.; Kontopoulos, A. Mechanisms of dissolution of iron oxides in aqueous oxalic acid solutions. Hydrometallurgy 1996, 42, 257-265. [CrossRef]

307. Yiyong, Z. UV-sensitive P compounds: Release mechanism, seasonal fluctuation and inhibitory effects on alkaline phosphatase activity in a shallow Chinese freshwater lake (Donghu Lake). Hydrobiologia 1996, 335, 55-62. [CrossRef]

308. Cotner, J.B.; Heath, R.T. Iron redox effects on photosensitive phosphorus release from dissolved humic materials. Limnol. Oceanogr. 1990, 35, 1175-1181. [CrossRef]

309. Francko, D.A.; Heath, R.T. Abiotic uptake and photo-dependent release of phosphate from high-molecular-weight humic-iron complexes in bog lake. In Aquatic and Terrestrial Humic Materials; Christman, R.F., Gjessing, E.T., Eds.; Ann Arbor Science Publishers: Ann Arbor, MI, USA, 1983; pp. 467-480.

310. Rose, A.L.; and Waite, T.D. Reduction of organically complexed ferric iron by superoxide in a simulated natural water. Environ. Sci. Technol. 2005, 39, 2645-2650. [CrossRef]

311. Rose, A.L.; and Waite, T.D. Role of superoxide in the photochemical reduction of iron in seawater. Geochim. Cosmochim. Acta 2006, 70, 3869-3882. [CrossRef]

312. Stumm, W.; Lee, G.F. Oxygenation of ferrous iron. Ind. Eng. Chem. 1961, 53, 143-146. [CrossRef]

313. Singer, P.C.; Stumm, W. Oxygenation of Ferrous Iron; Water Pollution Control Research Series Report. 14010, FWPCA, USA; Department of the Interior: Washington, DC, USA, 1970. 
314. Machiela, R.; Zhang, L.; Zhang, M.; Eisele, T. Regeneration of alkali leaching solution through precipitation using calcium hydroxide. Hydrometallurgy 2018, 181, 35-42. [CrossRef]

315. Monte, H.M.D.; Albuquerque, A. Reutilização de Águas Residuais. Guia Técnico nº 14, ERSAR, Lisboa, Portugal. Available online: https://www.pseau.org/outils/ouvrages/esrar_guia_14_reutilizacao_de_aguas_ residuais.pdf (accessed on 5 April 2018).

316. Henze, M.; Comeau, Y. Wastewater characterization. In Biological Wastewater Treatment: Principles Modelling and Design; Henze, M., van Loosdrecht, M.C.M., Ekama, G.A., Brdjanovic, D., Eds.; IWA Publishing: London, UK, 2008; pp. 33-52.

317. Henze, M.; Harremoes, P.; la Cour Jansen, J.; Arvin, E. Wastewater Treatment: Biological and Chemical Processes; Springer Science \& Business Media: Berlin, Germany, 2001.

318. Sun, J.; Xiu, Y.F.; Huang, K.; Yu, J.T.; Alam, S.; Zhu, H.M.; Guo, Z.C. Selective recovery of phosphorus from acid leach liquor of iron ore by garlic peel adsorbent. RSC Adv. 2018, 8, 22276-22285. [CrossRef]

319. Zhang, Y.; Muhammed, M. An integrated process for the treatment of apatite obtained from dephosphorization of iron ore. J. Chem. Technol. Biotechnol. 1990, 47, 47-60. [CrossRef]

320. Bisaka, K.; Thobadi, I.C.; Pawlik, C. Extraction of rare earths from iron-rich rare earth deposits. J. S. Afr. Inst. Min. Metall. 2017, 117, 731-739. [CrossRef]

321. Sun, T.; Kennedy, M.W.; Tranell, G.; Aune, R.E. Apatite concentrate, a potential new source of rare earth elements. In Rare Metal Technology 2015; Neelameggham, N.R., Alam, S., Oosterhof, H., Jha, A., Dreisinger, D., Wang, S., Eds.; Springer: Cham, Switzerland, 2015; pp. 145-156. [CrossRef]

322. Pålsson, B.I.; Martinsson, O.; Wanhainen, C.; Fredriksson, A. September. Unlocking rare earth elements from European apatite-iron ores. In Proceedings of the 1st European Rare Earth Resources Conference (ERES2014), Milos island, Greece, 4-7 September 2014; pp. 211-220.

323. Tehrani, P.N.; Calagari, A.A.; Roldan, F.V.; Simmonds, V.; Siahcheshm, K. C and O stable isotopes and rare earth elements in the Devonian carbonate host rock of the Pivehzhan iron deposit, NE Iran. Geol. Acta 2018, 16, 125-148. [CrossRef]

324. Jorjani, E.; Bagherieh, A.H.; Rezai, B. Determination of rare earth elements in products of Chadormalu iron ore concentrator plant (Iran) from beneficiation point of view. Iran. J. Chem. Chem. Eng. 2007, 26, 11-18.

325. De Amorim Dinis, M.L.P.; De Sousa, A.B. Mineral resources in Portugal-An Overview. In Mineral Resource Base of the Southern Caucasus and Systems for its Management in the XXI Century; NATO Science Series (Series IV: Earth and Environmental Sciences); Tvalchrelidze, A.G., Morizot, G., Eds.; Springer: Dordrecht, The Netherlands, 2003; Volume 17. [CrossRef]

326. Tóth, G.; Guicharnaud, R.A.; Tóth, B.; Hermann, T. Phosphorus levels in croplands of the European Union with implications for P fertilizer use. Eur. J. Agron. 2014, 55, 42-52. [CrossRef]

327. Ueno, Y.; Fuji, M. Three years experience of operating and selling recovered struvite from full scale plant. Environ. Technol. 2001, 22, 1373-1381. [CrossRef]

328. Cornel, P.; Schaum, C. Phosphorus recovery from wastewater: Needs, technologies and costs. Water Sci. Technol. 2009, 59, 1069-1076. [CrossRef]

329. Cordell, D.; Rosemarin, A.; Schröder, J.J.; Smit, A.L. Towards global phosphorus security: A systems framework for phosphorus recovery and reuse options. Chemosphere 2011, 84, 747-758. [CrossRef]

330. Vaccari, D.A. Phosphorus: A looming crisis. Sci. Am. 2009, 300, 54-59. [CrossRef]

331. Mohr, S.; Evans, G. Projections of Future Phosphorus Production. Philica. 2013. Available online: http://www.resilience.org/wpcontent/uploads/articles/General/2013/09_Sep/peakphosphorus/

Phosphorus\%20Projections.pdf (accessed on 10 March 2018).

332. Driver, J.; Lijmbach, D.; Steen, I. Why recover phosphorus for recycling, and how? Environ. Technol. 1999, 20, 651-662. [CrossRef]

333. Schoumans, O.F.; Bouraoui, F.; Kabbe, C.; Oenema, O.; van Dijk, K.C. Phosphorus management in Europe in a changing world. AMBIO 2015, 44, 180-192. [CrossRef]

334. Ashley, K.; Cordell, D.; Mavinic, D. A brief history of phosphorus: From the philosopher's stone to nutrient recovery and reuse. Chemosphere 2011, 84, 737-746. [CrossRef]

335. Desmidt, E.; Ghyselbrecht, K.; Zhang, Y.; Pinoy, L.; Van der Bruggen, B.; Verstraete, W.; Rabaey, K.; Meesschaert, B. Global phosphorus scarcity and full-scale P-recovery techniques: A review. Crit. Rev. Environ. Sci. Technol. 2015, 45, 336-384. [CrossRef] 
336. Koppelaar, R.H.E.M.; Weikard, H.P. Assessing phosphate rock depletion and phosphorus recycling options. Glob. Environ. Chang. 2013, 23, 1454-1466. [CrossRef]

337. Rittmann, B.E.; Mayer, B.; Westerhoff, P.; Edwards, M. Capturing the lost phosphorus. Chemosphere 2011, 84, 846-853. [CrossRef]

338. Withers, P.J.; van Dijk, K.C.; Neset, T.S.S.; Nesme, T.; Oenema, O.; Rubæk, G.H.; Schoumans, O.F.; Smit, B.; Pellerin, S. Stewardship to tackle global phosphorus inefficiency: The case of Europe. AMBIO 2015, 44, 193-206. [CrossRef]

339. Mayer, B.K.; Baker, L.A.; Boyer, T.H.; Drechsel, P.; Gifford, M.; Hanjra, M.A.; Parameswaran, P.; Stoltzfus, J.; Westerhoff, P.; Rittmann, B.E. Total value of phosphorus recovery. Environ. Sci. Technol. 2016, 50, 6606-6620. [CrossRef]

340. Cordell, D.; Drangerta, J.-O.; White, S. The story of phosphorus: Global food security and food for thought. Glob. Environ. Chang. 2009, 2, 292-305. [CrossRef]

341. EU Comission. Comission of the European. 29 May 2015. Available online: https://ec.europa.eu/transparency/ regdoc/rep/1/2015/EN/1-2015-229-EN-F1-1.PDF (accessed on 27 April 2018).

342. Hukari, S.; Hermann, L.; Nättorp, A. From wastewater to fertilisers-technical overview and critical review of European legislation governing phosphorus recycling. Sci. Total Environ. 2016, 542, 1127-1135. [CrossRef]

343. Roy, E.D. Phosphorus recovery and recycling with ecological engineering: A review. Ecol. Eng. 2017, 98, 213-227. [CrossRef]

344. Childers, D.L.; Corman, J.; Edwards, M.; Elser, J.J. Sustainability challenges of phosphorus and food: Solutions from closing the human phosphorus cycle. Bioscience 2011, 61, 117-124. [CrossRef]

345. Egle, L.; Rechberger, H.; Krampe, J.; Zessner, M. Phosphorus recovery from municipal wastewater: An integrated comparative technological, environmental and economic assessment of P recovery technologies. Sci. Total Environ. 2016, 571, 522-542. [CrossRef]

346. Le Corre, K.S.; Valsami-Jones, E.; Hobbs, P.; Parsons, S.A. Phosphorus recovery from wastewater by struvite crystallization: A review. Crit. Rev. Environ. Sci. Technol. 2009, 39, 433-477. [CrossRef]

347. Lanning, M.-C.E. Phosphate Recovery from Wastewaters Comparing Two Different Sources of Magnesium Oxide in the Precipitation of Struvite. Master's Thesis, The University of Guelph, Guelph, ON, Canada, September 2008.

348. Hermann, L. Recovery of Phosphorus from Wastewater Treatment. A Review. (Rückgewinnung von Phosphor aus der Abwassereinigung. Eine Bestandesaufnahme); Umwelt-Wissen Nr. 0929; Bundesamt für Umwelt (BAFU): Bern, Switzerland, 2009. (In German)

349. Valsami-Jones, E. Mineralogical controls on phosphorus recovery from wastewaters. Mineral. Mag. 2001, 65, 611-620. [CrossRef]

350. Kabbe, C.; Remy, C.; Kraus, F. Review of Promising Methods for Phosphorus Recovery E Recycling from Wastewater; International Fertiliser Society: Colchester, UK, 2015.

351. Pratt, C.; Parsons, S.A.; Soares, A.; Martin, B.D. Biologically and chemically mediated adsorption and precipitation of phosphorus from wastewater. Curr. Opin. Biotechnol. 2012, 23, 890-896. [CrossRef]

352. Saktaywin, W.; Tsuno, H.; Nagare, H.; Soyama, T.; Weerapakkaroon, J. Advanced sewage treatment process with excess sludge reduction and phosphorus recovery. Water Res. 2005, 39, 902-910. [CrossRef]

353. Blöcher, C.; Niewersch, C.; Melin, T. Phosphorus recovery from sewage sludge with a hybrid process of low-pressure wet oxidation and nanofiltration. Water Res. 2012, 46, 2009-2019. [CrossRef]

354. Güney, K.; Weidelener, A.; Krampe, J. Phosphorus recovery from digested sewage sludge as MAP by the help of metal ion separation. Water Res. 2008, 42, 4692-4698. [CrossRef]

355. Sano, A.; Kanomata, M.; Inoue, H.; Sugiura, N.; Xu, K.Q.; Inamori, Y. Extraction of raw sewage sludge containing iron phosphate for phosphorus recovery. Chemosphere 2012, 89, 1243-1247. [CrossRef]

356. Havukainen, J.; Nguyen, M.T.; Hermann, L.; Horttanainen, M.; Mikkilä, M.; Deviatkin, I.; Linnanen, L. Potential of phosphorus recovery from sewage sludge and manure ash by thermochemical treatment. Waste Manag. 2016, 49, 221-229. [CrossRef]

357. Acelas, N.Y.; López, D.P.; Brilman, D.W.; Kersten, S.R.; Kootstra, A.M.J. Supercritical water gasification of sewage sludge: Gas production and phosphorus recovery. Bioresour. Technol. 2014, 174, 167-175. [CrossRef]

358. Matsubae-Yokoyama, K.; Kubo, H.; Nagasaka, T. Recycling effects of residual slag after magnetic separation for phosphorus recovery from hot metal dephosphorization slag. ISIJ Int. 2010, 50, 65-70. [CrossRef] 
359. Matsubae-Yokoyama, K.; Kubo, H.; Nakajima, K.; Nagasaka, T. A material flow analysis of phosphorus in Japan: The iron and steel industry as a major phosphorus source. J. Ind. Ecol. 2009, 13, 687-705. [CrossRef]

360. Claveau-Mallet, D.; Wallace, S.; Comeau, Y. Removal of phosphorus, fluoride and metals from a gypsum mining leachate using steel slag filters. Water Res. 2013, 47, 1512-1520. [CrossRef]

361. Liang, H.; Zhang, P.; Jin, Z.; DePaoli, D. Rare Earth and Phosphorus Leaching from a Flotation Tailings of Florida Phosphate Rock. Minerals 2018, 8, 416. [CrossRef]

362. Guedes, P.; Couto, N.; Ottosen, L.M.; Ribeiro, A.B. Phosphorus recovery from sewage sludge ash through an electrodialytic process. Waste Manag. 2014, 34, 886-892. [CrossRef]

363. Petzet, S.; Peplinski, B.; Cornel, P. On wet chemical phosphorus recovery from sewage sludge ash by acidic or alkaline leaching and an optimized combination of both. Water Res. 2012, 46, 3769-3780. [CrossRef]

364. Nakagawa, H.; Ohta, J. Phosphorus Recovery from Sewage Sludge Ash: A Case Study in Gifu, Japan. In Phosphorus Recovery and Recycling; Springer: Singapore, 2019; pp. 149-155. [CrossRef]

365. Adam, C.; Peplinski, B.; Michaelis, M.; Kley, G.; Simon, F.G. Thermochemical treatment of sewage sludge ashes for phosphorus recovery. Waste Manag. 2009, 29, 1122-1128. [CrossRef]

366. Schoumans, O.F.; Rulkens, W.H.; Oenema, O.; Ehlert, P.A.I. Phosphorus Recovery from Animal Manure: Technical Opportunities and Agro-Economical Perspectives; Alterra Report No. 2158; Alterra: Wageningen, The Netherlands, December 2010; Available online: http:/content.alterra.wur.nl/Webdocs/PDFFiles/ Alterrarapporten/AlterraRapport2158.pdf (accessed on 30 April 2018).

367. Van Rutten, A. Phosphate Recovery from Animal Manure: The Possibilities in The Netherlands; CEEP: Amsterdam, The Netherlands, 1998.

368. Tao, W.; Fattah, K.P.; Huchzermeier, M.P. Struvite recovery from anaerobically digested dairy manure: A review of application potential and hindrances. J. Environ. Manag. 2016, 169, 46-57. [CrossRef]

369. Pan, S.H.; Lo, K.V.; Liao, P.H.; Schreier, H. Microwave pretreatment for enhancement of phosphorus release from dairy manure. J. Environ. Sci. Health Part B 2006, 41, 451-458. [CrossRef]

370. Szoegi, A.A.; Vanotti, M.B.; Hunt, P.G. Phosphorus recovery from pig manure solids prior to land application. J. Environ. Manag. 2015, 157, 1-7. [CrossRef]

371. Fang, L.; Li, J.S.; Guo, M.Z.; Cheeseman, C.R.; Tsang, D.C.; Donatello, S.; Poon, C.S. Phosphorus recovery and leaching of trace elements from incinerated sewage sludge ash (ISSA). Chemosphere 2018, 193, 278-287. [CrossRef]

372. Mihelcic, J.R.; Fry, L.M.; Shaw, R. Global potential of phosphorus recovery from human urine and feces. Chemosphere 2011, 84, 832-839. [CrossRef]

373. Cid, C.A.; Jasper, J.T.; Hoffmann, M.R. Phosphate recovery from human waste via the formation of hydroxyapatite during electrochemical wastewater treatment. ACS Sustain. Chem. Eng. 2018, 6, 3135-3142. [CrossRef]

374. Tilley, E.; Atwater, J.; Mavinic, D. Recovery of struvite from stored human urine. Environ. Technol. 2008, 29, 797-806. [CrossRef]

375. Antonini, S.; Paris, S.; Eichert, T.; Clemens, J. Nitrogen and phosphorus recovery from human urine by struvite precipitation and air stripping in Vietnam. CLEAN-Soil Air Water 2011, 39, 1099-1104. [CrossRef]

376. Liu, B.; Giannis, A.; Zhang, J.; Chang, V.W.C.; Wang, J.Y. Characterization of induced struvite formation from source-separated urine using seawater and brine as magnesium sources. Chemosphere 2013, 93, 2738-2747. [CrossRef]

377. Chapple, K. Defining the Green Economy: A Primer on Green Economic Development; The Center for Community Innovation (CCI) at UC-Berkeley: Berkeley, CA, USA, 2008; p. 66.

378. Krugman, P. Building a Green Economy. The New York Times Magzine. 7 April 2010, Volume 5. pp. 2-16. Available online: https://www.ohipl.org/sites/default/files/KrugmanNYT.pdf (accessed on 10 March 2019).

379. Borel-Saladin, J.M.; Turok, I.N. The green economy: Incremental change or transformation? Environ. Policy Gov. 2013, 23, 209-220. [CrossRef]

380. Brand, U. Green economy-The next oxymoron? No lessons learned from failures of implementing sustainable development. GAIA-Ecolo. Perspect. Sci. Soc. 2012, 21, 28-32. [CrossRef]

381. Barbier, E. The policy challenges for green economy and sustainable economic development. In Natural Resources Forum; Blackwell Publishing Ltd.: Oxford, UK, 2011; Volume 35, pp. 233-245. [CrossRef]

382. Sheldon, R.A. Green chemistry and resource efficiency: Towards a green economy. Green Chem. 2016, 18, 3180-3183. [CrossRef] 
383. Heshmati, A. An empirical survey of the ramifications of a green economy. Int. J. Green Econ. 2018, 12, 53-85. [CrossRef]

384. Lieder, M.; Rashid, A. Towards circular economy implementation: A comprehensive review in context of manufacturing industry. J. Clean. Prod. 2016, 115, 36-51. [CrossRef]

385. Geissdoerfer, M.; Savaget, P.; Bocken, N.M.; Hultink, E.J. The circular economy-A new sustainability paradigm? J. Clean. Prod. 2017, 143, 757-768. [CrossRef]

386. Kirchherr, J.; Reike, D.; Hekkert, M. Conceptualizing the circular economy: An analysis of 114 definitions. Resour. Conserv. Recycl. 2017, 127, 221-232. [CrossRef]

387. Kalmykova, Y.; Sadagopan, M.; Rosado, L. Circular economy-From review of theories and practices to development of implementation tools. Resour. Conserv. Recycl. 2018, 135, 190-201. [CrossRef]

388. Prieto-Sandoval, V.; Jaca, C.; Ormazabal, M. Towards a consensus on the circular economy. J. Clean. Prod. 2018, 179, 605-615. [CrossRef]

389. Reike, D.; Vermeulen, W.J.; Witjes, S. The circular economy: New or refurbished as CE 3.0?-Exploring controversies in the conceptualization of the circular economy through a focus on history and resource value retention options. Resour. Conserv. Recycl. 2018, 135, 246-264. [CrossRef]

390. Cordell, D.; White, S. Peak phosphorus: Clarifying the key issues of a vigorous debate about long-term phosphorus security. Sustainability 2011, 3, 2027-2049. [CrossRef]

391. Villalba, G.; Liu, Y.; Schroder, H.; Ayres, R.U. Global phosphorus flows in the industrial economy from a production perspective. J. Ind. Ecol. 2008, 12, 557-569. [CrossRef]

392. Rabchevsky, G. Phosphate Roc; Geological Survey: Reston, VA, USA, 1995.

393. Lauriente, D.H. Phosphate Rock; Stanford Research Institute: Menlo Park, CA, USA, 2003.

394. Jasinski, S.M. Phosphate Rock; Geological Survey: Reston, VA, USA, 2005.

395. Parikh, P. Geopolitics and the (In)Security of EU's Phosphate Imports. 2014. Available online: http: //phosphateprice.com/geopolitics-and-the-insecurity-of-eus-phosphate-imports (accessed on 10 October 2018).

396. Van der Hoeven, D. Geopolitics of Phosphate in a Biobased Economy. 2017. Available online: https://www. biobasedpress.eu/2017/11/geopolitics-of-phosphate-a-biobased-economy (accessed on 10 October 2018).

397. Van Kauwenbergh, S.J. World Phosphate Rock Reserves and Resources; International Fertilizer Development Centre (IFDC): Muscle Shoals, AL, USA, 2010.

398. Jasinski, S.M. Phosphate Rock, Mineral Commodity Summaries; US Geological Survey: Reston, VA, USA, 2011.

399. Mancheri, N.A. World trade in rare earths, Chinese export restrictions, and implications. Resour. Policy 2015, 46, 262-271. [CrossRef]

400. Wübbeke, J. Rare earth elements in China: Policies and narratives of reinventing an industry. Resour. Policy 2013, 38, 384-394. [CrossRef]

401. García, M.V.R.; Krzemień, A.; del Campo, M.Á.M.; Álvarez, M.M.; Gent, M.R. Rare earth elements mining investment: It is not all about China. Resour. Policy 2017, 53, 66-76. [CrossRef]

402. Zhang, L.; Qing, G.U.O.; Zhang, J.; Huang, Y.; Xiong, T. Did China's rare earth export policies work?-Empirical evidence from USA and Japan. Resour. Policy 2015, 43, 82-90. [CrossRef]

403. Massari, S.; Ruberti, M. Rare earth elements as critical raw materials: Focus on international markets and future strategies. Resour. Policy 2013, 38, 36-43. [CrossRef]

404. Klinger, J.M. Rare earth elements: Development, sustainability and policy issues. Extr. Ind. Soc. 2018, 5, 1-7. [CrossRef]

405. Cox, C.; Kynicky, J. The rapid evolution of speculative investment in the REE market before, during, and after the rare earth crisis of 2010-2012. Extr. Ind. Soc. 2018, 5, 8-17. [CrossRef]

406. Charalampides, G.; Vatalis, K.I.; Apostoplos, B.; Ploutarch-Nikolas, B. Rare earth elements: Industrial applications and economic dependency of Europe. Procedia Econ. Finance 2015, 24, 126-135. [CrossRef]

407. Golev, A.; Scott, M.; Erskine, P.D.; Ali, S.H.; Ballantyne, G.R. Rare earths supply chains: Current status, constraints and opportunities. Resour. Policy 2014, 41, 52-59. [CrossRef]

408. Cruz, E.D. China's Iron Ore Hits 16-Month High after Vale Dam Disaster. 2019. Available online: https://www.reuters.com/article/us-asia-ironore/chinas-iron-ore-hits-16-month-high-aftervale-dam-disaster-idUSKCN1PM0LP (accessed on 5 April 2019). 
409. Treadgold, T. Iron Ore Price Surges Higher after Second Dam Collapse in Brazil. 2019. Available online: https://www.forbes.com/sites/timtreadgold/2019/01/29/iron-ore-price-surges-higher-aftersecond-dam-collapse-in-brazil/\#62fdad3d6fcf (accessed on 5 April 2019).

410. CRU: Vale's Dam Accident to Have Significant Impact on the Iron Ore Market. Available online: https://www.prnewswire.com/news-releases/cru-vales-dam-accident-to-have-significant-impact-on-theiron-ore-market-300793304.html (accessed on 6 April 2019).

(c) (1)

(C) 2019 by the author. Licensee MDPI, Basel, Switzerland. This article is an open access article distributed under the terms and conditions of the Creative Commons Attribution (CC BY) license (http://creativecommons.org/licenses/by/4.0/). 